\title{
Estimating Case Fatality and Case \\ Recovery Rates of COVID-19: is \\ this the right thing to do?
}

\section{Morteza Abdullatif Khafaie ${ }^{1}$ and Fakher Rahim²*}

${ }^{1}$ Social Determinants of Health Research Center, Ahvaz Jundishapur University of Medical Sciences, Ahvaz, Iran;

${ }^{2}$ Thalassemia \& Hemoglobinopathy Research

Center, Health Research Institute, Ahvaz

Jundishapur University of Medical Sciences,

Ahvaz, Iran;

*Corresponding Author email:

bioinfo2003@gmail.com

\section{(cc) EY}

New articles in this journal are licensed under a Creative Commons Attribution 4.0 United States License.

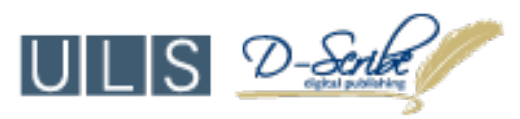

This journal is published by the University Library System of the University of Pittsburgh as part of its D-Scribe Digital Publishing Program and is cosponsored by the University of Pittsburgh Press. 


\section{Abstract}

Introduction: Case fatality rates (CFRs) and case recovery rates (CRRs) are frequently used to define health consequences related to specific disease epidemics, including the COVID-19 pandemic. This study aimed to compare various methods and models for calculating CFR and CRR related to COVID-19 based on the global and national data available as of April 2020.

Methods: This analytical epidemiologic study was conducted based on detailed data from 210 countries and territories worldwide in April 2020. We used three different formulas to measure CFR and CRR, considering all possible scenarios.

Results: We included information for 72 countries with more than 1,000 cases of COVID-19. Overall, using first, second, and third estimation models, the CFR were $6.22 \%, 21.20 \%$, and $8.67 \%$, respectively; similarly, the CRR was estimated as $23.21 \%, 78.86 \%$, $32.23 \%$, respectively. We have shown that CFRs vary so much spatially and depend on the estimation method and timing of case reports, likely resulting in overestimation.

Conclusion: Even with the more precise method of CFRs estimation, the value is overestimated. Case fatality and recovery rates should not be the only measures used to evaluate disease severity, and the better assessment measures need to be developed as indicators of countries' performance during COVID-19 pandemic.

Keywords: Coronavirus; COVID-19; Case fatality rates; CFRs; Case recovery rates; CRRs

\section{Estimating Case Fatality and Case Recovery Rate of COVID-19: is this the right thing to do?}

\author{
Morteza Abdullatif Khafaie ${ }^{1}$ and \\ Fakher Rahim ${ }^{2 *}$
}

\begin{abstract}
${ }^{1}$ Social Determinants of Health Research Center, Ahvaz Jundishapur University of Medical Sciences, Ahvaz, Iran; ${ }^{2}$ Thalassemia \& Hemoglobinopathy Research Center, Health Research Institute, Ahvaz Jundishapur University of Medical Sciences, Ahvaz, Iran;
\end{abstract}

\section{*Corresponding Author email: bioinfo2003@gmail.com}

\section{Research}

In late December 2019, a series of unexplained pneumonia cases were reported in Wuhan, China, which led government and researchers in China to take quick action to control its spread and start a large number of etiologic studies. ${ }^{1}$ On January 30, 2020, WHO declared the epidemic of the virus as a public health emergency with international concern (PHEIC). ${ }^{2}$ COVID-19 has spread to more than 210 countries and territories around the world, and as of December 2020, nearly 1.7 million lives have been lost. ${ }^{3}$ The virus spreads through droplets after infected persons cough or sneeze, which may enter the body through inhalation or contact with contaminated surfaces, and then touching the eyes, nose, and mouth. ${ }^{5}$ According to scientists, the average time required for symptoms to appear is 5 days, but in some cases and situations, it may take much longer, as the virus' incubation period lasts up to 14 days. ${ }^{6}$

Case fatality rates (CFRs) and case recovery rates (CRRs) are frequently used to define health consequences related to certain disease epidemics, as well as for the COVID-19 outbreak. ${ }^{7}$ CFR is the

This work is licensed under a Creative Commons Attribution 4.0 United States License.

This journal is published by the University Library System of the University of Pittsburgh as part of its D-Scribe Digital Publishing Program and is cosponsored by the University of Pittsburgh Press. 
proportion of deaths due to a specified health condition compared to total infected cases. ${ }^{8}$ Calculations are based on the controversial assumption that all of patients were tested. COVID-related CFR might be either overestimated or underestimated depending on if calculations are based on every confirmed case or only those cases who have recovered or died. Specialists in epidemiology have proposed different scenarios for calculating CFR, each with its advantages and disadvantages. ${ }^{9-11} \mathrm{CRR}$ is the proportion of recovered or discharged individuals with a specified health condition compared to total infected cases. ${ }^{12}$

The absence of reliable numbers of infected cases for the entire population could lead to inaccurate calculation of the CFR and CRR due to lack of a valid denominator. There has been an urgent need for these reported data to be openly available, so estimates of CFR and CRR can be estimated as accurately as possible. This study aimed to compare various introduced methods and models for the calculation of CFR and CRR related to COVID-19 over a time based on the recent global and national data.

\section{Methods}

\section{Design and setting}

This analytical epidemiologic study was conducted using detailed data from 210 countries and territories available around the world as of April 17, 2020. The current survey was approved by the Ahvaz Jundishapur University of Medical Sciences Ethical Committee.

\section{Source of data and procedure}

We used a method that our research team recently published to retrieve data and estimate CFR and CRR. ${ }^{13}$ In brief, the data about total cases, total deaths, and total recovered cases, alongside total screening tests used to diagnose COVID-19, were collected from the world's most acceptable and accurate data repositories, including $\mathrm{WHO}^{14}$, Worldometer ${ }^{4}$, the Centers for Disease Control and Prevention, and the Morbidity and Mortality Weekly Report series (provided from Centers for Disease Control and Prevention) $)^{15}$, consistent with the user's guide of data sources for patient registries. ${ }^{16}$ The data analyses were performed between April 17-19, 2020. Data were measured and analyzed for each country, and CFR and CRR for countries with $\geq 1,000$ cases ( $n=72$ ) are presented in the main tables. Data for the remaining countries with $<1,000$ cases $(n=138)$ are accessible in the supplementary tables.

\section{Measuring the CFR and CRR}

Given the difficulty of estimating CFR and CRR accurately during the ongoing COVID-19 pandemic, we used three different methods to estimate CFR and CRR, considering all possible scenarios (Figure 1).

\section{Formula I}

According to Battegay et al., we used the proportion of total deaths and recovered cases of COVID-19 disease to total cases of disease at global and national levels to estimate CFRs and CRRs, respectively. ${ }^{17}$

$\mathrm{CFR}=($ Total deaths attributed to COVID-19/

Total cases of COVID-19) $* 100$

$\mathrm{CRR}=($ Total recovered individuals attributed to

COVID-19/Total cases of COVID-19) * 100

\section{Formula II}

Another method, proposed by Ghani et al., to estimate CFRs and CRRs is merely considering the summation of the current total deaths plus current total recovered as the denominator. ${ }^{18}$

$\mathrm{CFR}=$ Total deaths attributed to

COVID-19/(deaths+recovered)

$\mathrm{CRR}=$ Total recovered individuals attributed

to COVID-19/(deaths+recovered)

This work is licensed under a Creative Commons Attribution 4.0 United States License.

This journal is published by the University Library System of the University of Pittsburgh as part of its D-Scribe Digital Publishing Program and is cosponsored by the University of Pittsburgh Press.

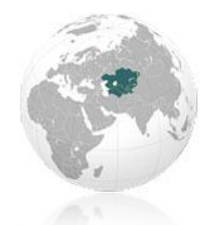


Formula III

This formula accounts for the lag time between an individual's disease onset and death/recovery. ${ }^{4} \mathrm{~T}$ is the average time from emerging symptoms until the onset of death (or recovery). Since most countries had not adopted well-performing detection systems, to avoid overestimating the rates, $T$ was considered 7 days, which is the difference of the minimum reported time between the onset of symptom to outcomes and the maximum incubation period. ${ }^{19}$

$\mathrm{CFR}=$ Deaths at day $\mathrm{x} /$ Total cases at day $\mathrm{x}-\mathrm{T}$

$\mathrm{CRR}=$ Recovered at day $\mathrm{x} /$ Total cases at day $\mathrm{x}-\mathrm{T}$

\section{Statistical analysis}

Data management and calculation were conducted in Microsoft Excel, and results (CF and CR rates) were tabulated for the three standard methods of rate estimation by countries. We reported information for the 72 countries in the body of the paper with more than 1,000 cases of COVID-19 in the main paper, and the estimates of the remaining countries $(n=138)$ were provided as supplementary tables. Overall rates for the world were also calculated.
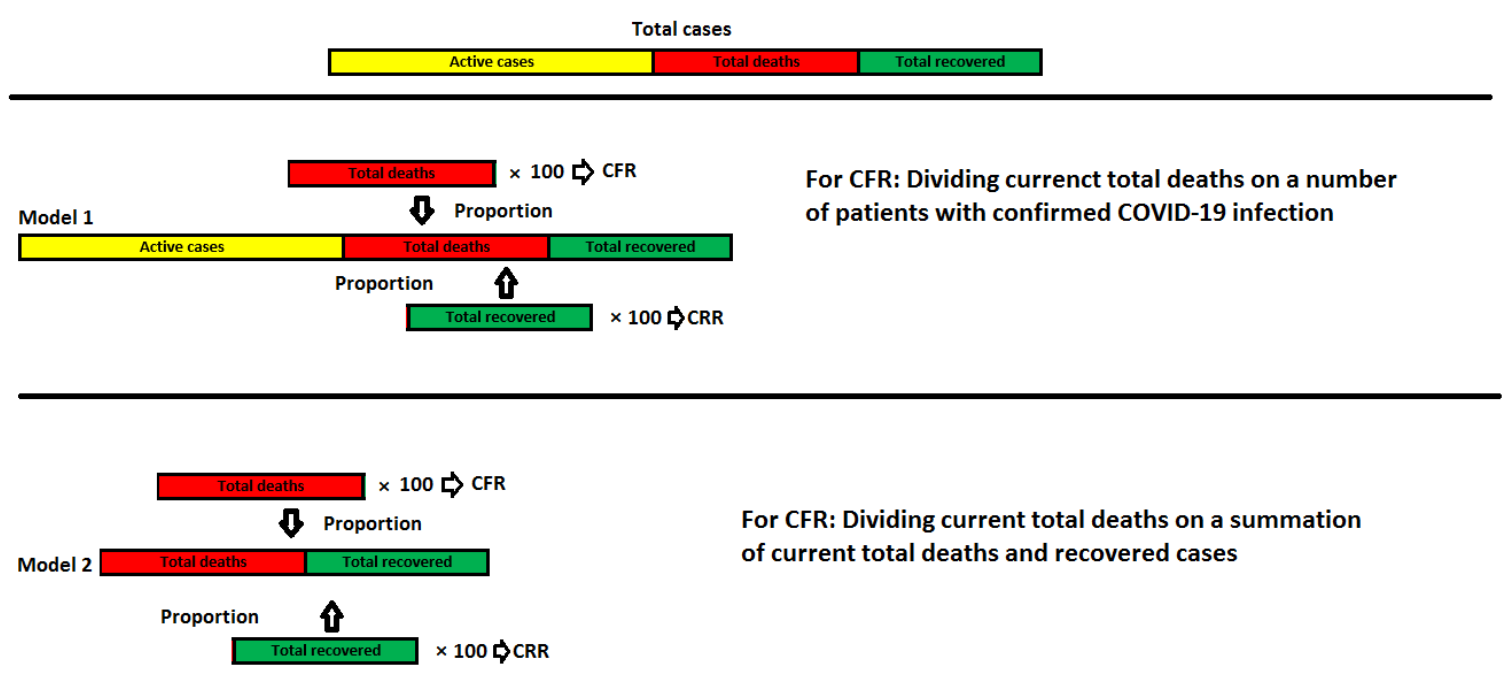

For CFR: Dividing current total deaths on a summation of current total deaths and recovered cases

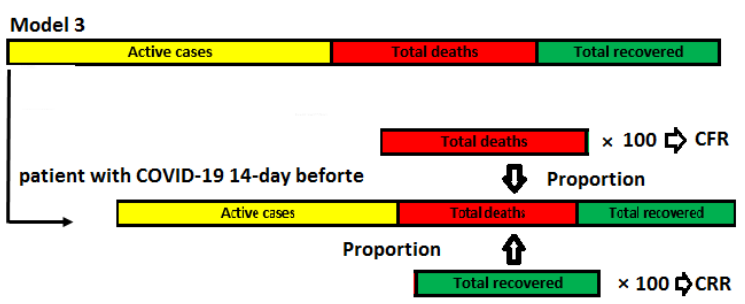

For CFR: Dividing the number of deaths in a given day by a number of patients with confirmed COVID19 infection 14-day before

Figure 1. Schematic illustration of three different conceivable models for CFR and CRR calculation

This work is licensed under a Creative Commons Attribution 4.0 United States License.

This journal is published by the University Library System of the University of Pittsburgh as part of its D-Scribe Digital Publishing Program and is cosponsored by the University of Pittsburgh Press. 


\section{Results}

The total number of reported cases from the beginning of the epidemic until April 17, 2020 was $1,925,179$. The USA had the highest number of COVID19 cases detected $(n=578,155 ; 30.5 \%$ of global cases $)$, followed by Spain and Italy with 170,099 (8.84\%) and $159,516(8.29 \%)$ cases, respectively. Table 1 shows global as well as national data on the COVID-19 healthrelated consequences. Global CFRs for COVID-19 estimated by first, second, and third methods were $6.22 \%, 21.20 \%$, and $8.67 \%$, respectively. Similarly, CRRs were estimated as $23.21 \%, 78.86 \%, 32.23 \%$. The third method, which is the more precise and widely accepted method, shows that Algeria (19.17\%), Belgium $(18.39 \%)$, and the UK (18.38\%) account for the highest CFRs. Data about all countries with confirmed cases less than 1,000 were presented in Table S1.

Considering the first estimation model, the highest CRRs were in China, South Korea, and Iran. Given the second estimation model, most countries such as Germany, China, Iran, Switzerland, Canada, and Austria had CRR above $90 \%$. Based on the third estimation model, several countries, including China, Turkey, Russia, Sweden, and Peru, had CRRs higher than 90\% (Table 1).
The overall lowest and highest CFR and CRR in the European continent were estimated by model 1 and model 2, respectively (Table 2). The highest CFR was observed in the European continent using models 1 and 3; model 2 highlighted the North American continent as the region with the highest CFR (Table 2). Moreover, the highest CRR was observed in Oceania in all three models (Table 2).

The impact of important contributing factors affecting CFR and CRR such as the country's population, GDP, number of hospital beds per 1,000 people, number of ICU beds per 100,000 people, and number of ventilators were assessed in the three different proposed models of estimation (Table S2). Comparison among countries with high, moderate, and low CFR was illustrated in Figure 2.

Though the analysis showed a statistically nonsignificant pattern for all variables of interest, models 1 and 2 potentially provide more accurate estimates of CFR and CRR (Table 3). The WHO reported CFR for COVID19 as $2 \%{ }^{20}$; other calculated values are shown based on data and available literature in countries and at the global level (Table 4).

\begin{tabular}{|c|c|c|c|c|c|c|c|c|c|c|}
\hline \multirow{2}{*}{ Country } & \multirow{2}{*}{$\begin{array}{c}\text { Total } \\
\text { Recovered }\end{array}$} & \multirow{2}{*}{$\begin{array}{c}\text { Total } \\
\text { deaths }\end{array}$} & \multirow{2}{*}{$\begin{array}{l}\text { Total } \\
\text { cases }\end{array}$} & \multirow{2}{*}{$\begin{array}{c}\text { Active } \\
\text { cases }\end{array}$} & \multicolumn{2}{|c|}{ Model 1} & \multicolumn{2}{|c|}{ Model 2} & \multicolumn{2}{|c|}{ Model 3} \\
\hline & & & & & CFR1 & CRR1 & CFR2 & CRR2 & CFR3 & CRR3 \\
\hline USA & $3,950,354$ & 198,128 & $6,676,601$ & $2,528,119$ & $2.97 \%$ & $59 \%$ & $4.78 \%$ & $95.22 \%$ & $0.85 \%$ & $57.09 \%$ \\
\hline India & $3,702,595$ & 78,614 & $4,754,356$ & 973,147 & $1.65 \%$ & $78 \%$ & $2.08 \%$ & $97.92 \%$ & $0.49 \%$ & $75.34 \%$ \\
\hline Brazil & $3,553,421$ & 131,274 & $4,315,858$ & 631,163 & $3.04 \%$ & $82 \%$ & $3.56 \%$ & $96.44 \%$ & $0.63 \%$ & $80.79 \%$ \\
\hline Russia & 873,535 & 18,484 & $1,057,362$ & 165,343 & $1.75 \%$ & $83 \%$ & $2.07 \%$ & $97.93 \%$ & $2.20 \%$ & $78.31 \%$ \\
\hline Peru & 559,321 & 30,593 & 722,832 & 132,918 & $4.23 \%$ & $77 \%$ & $5.19 \%$ & $94.81 \%$ & $0.85 \%$ & $61.54 \%$ \\
\hline Colombia & 592,820 & 22,734 & 708,964 & 93,410 & $3.21 \%$ & $84 \%$ & $3.69 \%$ & $96.31 \%$ & $2.98 \%$ & ------ \\
\hline Mexico & 467,525 & 70,604 & 663,973 & 125,844 & $10.63 \%$ & $70 \%$ & $13.12 \%$ & $86.88 \%$ & $0.44 \%$ & $65.32 \%$ \\
\hline South Africa & 576,423 & 15,427 & 648,214 & 56,364 & $2.38 \%$ & $89 \%$ & $2.61 \%$ & $97.39 \%$ & $0.90 \%$ & $77.98 \%$ \\
\hline Spain & N/A & 29,747 & 576,697 & N/A & $5.16 \%$ & ---- & ----- & ------ & $0.14 \%$ & ------ \\
\hline Argentina & 409,771 & 11,263 & 546,481 & 125,447 & $2.06 \%$ & $75 \%$ & $2.68 \%$ & $97.32 \%$ & $0.85 \%$ & $60.79 \%$ \\
\hline Chile & 404,919 & 11,895 & 432,666 & 15,852 & $2.75 \%$ & $94 \%$ & $2.85 \%$ & $97.15 \%$ & $1.06 \%$ & $86.39 \%$ \\
\hline Iran & 344,516 & 23,029 & 399,940 & 32,395 & $5.76 \%$ & $86 \%$ & $6.27 \%$ & $93.73 \%$ & $0.68 \%$ & $81.57 \%$ \\
\hline France & 89,059 & 30,910 & 373,911 & 253,942 & $8.27 \%$ & $24 \%$ & $25.76 \%$ & $74.24 \%$ & $1.93 \%$ & $20.91 \%$ \\
\hline UK & N/A & 41,623 & 365,174 & N/A & $11.40 \%$ & ----- & ------- & ------ & $1.24 \%$ & ------- \\
\hline
\end{tabular}

This work is licensed under a Creative Commons Attribution 4.0 United States License.

This journal is published by the University Library System of the University of Pittsburgh as part of its D-Scribe Digital Publishing Program and is cosponsored by the University of Pittsburgh Press. 


\begin{tabular}{|c|c|c|c|c|c|c|c|c|c|c|}
\hline \multirow{2}{*}{ Country } & \multirow{2}{*}{$\begin{array}{c}\text { Total } \\
\text { Recovered }\end{array}$} & \multirow{2}{*}{$\begin{array}{c}\text { Total } \\
\text { deaths }\end{array}$} & \multirow{2}{*}{$\begin{array}{l}\text { Total } \\
\text { cases }\end{array}$} & \multirow{2}{*}{$\begin{array}{c}\text { Active } \\
\text { cases }\end{array}$} & \multicolumn{2}{|c|}{ Model 1} & \multicolumn{2}{|c|}{ Model 2} & \multicolumn{2}{|c|}{ Model 3} \\
\hline & & & & & CFR1 & CRR1 & CFR2 & CRR2 & CFR3 & CRR3 \\
\hline Bangladesh & 238,271 & 4,702 & 336,044 & 93,071 & $1.40 \%$ & $71 \%$ & $1.94 \%$ & $98.06 \%$ & $0.28 \%$ & $68.78 \%$ \\
\hline Saudi Arabia & 301,836 & 4,240 & 325,050 & 18,974 & $1.30 \%$ & $93 \%$ & $1.39 \%$ & $98.61 \%$ & $0.51 \%$ & $86.03 \%$ \\
\hline Pakistan & 289,429 & 6,379 & 301,481 & 5,673 & $2.12 \%$ & $96 \%$ & $2.16 \%$ & $97.84 \%$ & $0.26 \%$ & $93.21 \%$ \\
\hline Turkey & 257,731 & 6,999 & 289,635 & 24,905 & $2.42 \%$ & $89 \%$ & $2.64 \%$ & $97.36 \%$ & $0.32 \%$ & $88.52 \%$ \\
\hline Iraq & 221,283 & 7,941 & 286,778 & 57,554 & $2.77 \%$ & $77 \%$ & $3.46 \%$ & $96.54 \%$ & $0.23 \%$ & $76.62 \%$ \\
\hline Italy & 213,191 & 35,603 & 286,297 & 37,503 & $12.44 \%$ & $74 \%$ & $14.31 \%$ & $85.69 \%$ & $0.38 \%$ & $71.24 \%$ \\
\hline Germany & 235,300 & 9,427 & 260,546 & 15,819 & $3.62 \%$ & $90 \%$ & $3.85 \%$ & $96.15 \%$ & $0.87 \%$ & $89.92 \%$ \\
\hline Philippines & 187,116 & 4,292 & 257,863 & 66,455 & $1.66 \%$ & $73 \%$ & $2.24 \%$ & $97.76 \%$ & $0.06 \%$ & $71.58 \%$ \\
\hline Indonesia & 152,458 & 8,650 & 214,746 & 53,638 & $4.03 \%$ & $71 \%$ & $5.37 \%$ & $94.63 \%$ & $0.09 \%$ & $67.64 \%$ \\
\hline Israel & 113,496 & 1,103 & 152,722 & 38,123 & $0.72 \%$ & $74 \%$ & $0.96 \%$ & $99.04 \%$ & $0.94 \%$ & $68.37 \%$ \\
\hline Ukraine & 68,346 & 3,148 & 151,859 & 80,365 & $2.07 \%$ & $45 \%$ & $4.40 \%$ & $95.60 \%$ & $0.36 \%$ & $36.87 \%$ \\
\hline Canada & 120,075 & 9,170 & 136,141 & 6,896 & $6.74 \%$ & $88 \%$ & $7.10 \%$ & $92.90 \%$ & $0.01 \%$ & $87.39 \%$ \\
\hline Bolivia & 82,796 & 7,297 & 125,982 & 35,889 & $5.79 \%$ & $66 \%$ & $8.10 \%$ & $91.90 \%$ & $0.23 \%$ & $63.32 \%$ \\
\hline Qatar & 118,475 & 205 & 121,523 & 2,843 & $0.17 \%$ & $97 \%$ & $0.17 \%$ & $99.83 \%$ & $0.16 \%$ & $91.46 \%$ \\
\hline Ecuador & 91,242 & 10,864 & 116,451 & 14,345 & $9.33 \%$ & $78 \%$ & $10.64 \%$ & $89.36 \%$ & $0.33 \%$ & $76.72 \%$ \\
\hline Kazakhstan & 100,615 & 1,634 & 106,803 & 4,554 & $1.53 \%$ & $94 \%$ & $1.60 \%$ & $98.40 \%$ & $0.53 \%$ & $91.90 \%$ \\
\hline Dominican Republic & 76,531 & 1,953 & 103,092 & 24,608 & $1.89 \%$ & $74 \%$ & $2.49 \%$ & $97.51 \%$ & $0.62 \%$ & $71.19 \%$ \\
\hline Romania & 42,811 & 4,127 & 102,386 & 55,448 & $4.03 \%$ & $42 \%$ & $8.79 \%$ & $91.21 \%$ & $0.07 \%$ & $40.11 \%$ \\
\hline Panama & 73,476 & 2,155 & 101,041 & 25,410 & $2.13 \%$ & $73 \%$ & $2.85 \%$ & $97.15 \%$ & $0.01 \%$ & $71.66 \%$ \\
\hline Egypt & 83,261 & 5,627 & 100,856 & 11,968 & $5.58 \%$ & $83 \%$ & $6.33 \%$ & $93.67 \%$ & $0.08 \%$ & $80.48 \%$ \\
\hline Kuwait & 84,404 & 558 & 94,211 & 9,249 & $0.59 \%$ & $90 \%$ & $0.66 \%$ & $99.34 \%$ & $0.26 \%$ & $80.19 \%$ \\
\hline Belgium & 18,709 & 9,923 & 92,478 & 63,846 & $10.73 \%$ & $20 \%$ & $34.66 \%$ & $65.34 \%$ & $0.83 \%$ & $18.99 \%$ \\
\hline Oman & 83,325 & 762 & 88,337 & 4,250 & $0.86 \%$ & $94 \%$ & $0.91 \%$ & $99.09 \%$ & $0.25 \%$ & $93.35 \%$ \\
\hline Sweden & N/A & 5,846 & 86,505 & N/A & $6.76 \%$ & ---- & $100.00 \%$ & ----- & $0.49 \%$ & ---- \\
\hline China & 80,399 & 4,634 & 85,184 & 151 & $5.44 \%$ & $94 \%$ & $5.45 \%$ & $94.55 \%$ & $0.19 \%$ & $92.96 \%$ \\
\hline Morocco & 65,867 & 1,553 & 84,435 & 17,015 & $1.84 \%$ & $78 \%$ & $2.30 \%$ & $97.70 \%$ & $0.61 \%$ & $76.91 \%$ \\
\hline Guatemala & 70,403 & 2,949 & 81,658 & 8,306 & $3.61 \%$ & $86 \%$ & $4.02 \%$ & $95.98 \%$ & $0.25 \%$ & $86.18 \%$ \\
\hline Netherlands & N/A & 6,253 & 81,012 & N/A & $7.72 \%$ & ----- & $100.00 \%$ & ----- & $0.28 \%$ & ----- \\
\hline UAE & 68,983 & 399 & 78,849 & 9,467 & $0.51 \%$ & $87 \%$ & $0.58 \%$ & $99.42 \%$ & $0.11 \%$ & $80.38 \%$ \\
\hline Japan & 66,280 & 1,423 & 74,544 & 6,841 & $1.91 \%$ & $89 \%$ & $2.10 \%$ & $97.90 \%$ & $0.38 \%$ & $87.58 \%$ \\
\hline Belarus & 72,547 & 744 & 73,975 & 684 & $1.01 \%$ & $98 \%$ & $1.02 \%$ & $98.98 \%$ & $0.23 \%$ & $97.45 \%$ \\
\hline Poland & 59,725 & 2,182 & 73,650 & 11,743 & $2.96 \%$ & $81 \%$ & $3.52 \%$ & $96.48 \%$ & $0.21 \%$ & $80.92 \%$ \\
\hline Honduras & 17,760 & 2,065 & 67,136 & 47,311 & $3.08 \%$ & $26 \%$ & $10.42 \%$ & $89.58 \%$ & $0.15 \%$ & $20.56 \%$ \\
\hline Ethiopia & 24,493 & 996 & 63,888 & 38,399 & $1.56 \%$ & $38 \%$ & $3.91 \%$ & $96.09 \%$ & $0.40 \%$ & $36.44 \%$ \\
\hline Portugal & 43,894 & 1,860 & 63,310 & 17,556 & $2.94 \%$ & $69 \%$ & $4.07 \%$ & $95.93 \%$ & $0.14 \%$ & $67.01 \%$ \\
\hline Venezuela & 47,729 & 477 & 59,630 & 11,424 & $0.80 \%$ & $80 \%$ & $0.99 \%$ & $99.01 \%$ & $0.57 \%$ & $77.97 \%$ \\
\hline Bahrain & 53,192 & 211 & 59,586 & 6,183 & $0.35 \%$ & $89 \%$ & $0.40 \%$ & $99.60 \%$ & $0.32 \%$ & $85.07 \%$ \\
\hline Singapore & 56,699 & 27 & 57,357 & 631 & $0.05 \%$ & $99 \%$ & $0.05 \%$ & $99.95 \%$ & $0.28 \%$ & $97.64 \%$ \\
\hline Nigeria & 44,088 & 1,078 & 56,177 & 11,011 & $1.92 \%$ & $78 \%$ & $2.39 \%$ & $97.61 \%$ & $0.35 \%$ & $76.45 \%$ \\
\hline Costa Rica & 20,928 & 590 & 55,454 & 33,936 & $1.06 \%$ & $38 \%$ & $2.74 \%$ & $97.26 \%$ & $0.16 \%$ & $32.11 \%$ \\
\hline Nepal & 37,524 & 336 & 53,120 & 15,260 & $0.63 \%$ & $71 \%$ & $0.89 \%$ & $99.11 \%$ & $0.81 \%$ & $67.71 \%$ \\
\hline Algeria & 33,875 & 1,605 & 48,007 & 12,527 & $3.34 \%$ & $71 \%$ & $4.52 \%$ & $95.48 \%$ & $0.21 \%$ & $68.64 \%$ \\
\hline Uzbekistan & 43,511 & 386 & 46,850 & 2,953 & $0.82 \%$ & $93 \%$ & $0.88 \%$ & $99.12 \%$ & $0.05 \%$ & $90.71 \%$ \\
\hline Switzerland & 38,500 & 2,020 & 46,704 & 6,184 & $4.33 \%$ & $82 \%$ & $4.99 \%$ & $95.01 \%$ & $0.11 \%$ & $76.85 \%$ \\
\hline Armenia & 41,605 & 911 & 45,675 & 3,159 & $1.99 \%$ & $91 \%$ & $2.14 \%$ & $97.86 \%$ & $0.05 \%$ & $89.51 \%$ \\
\hline
\end{tabular}

This work is licensed under a Creative Commons Attribution 4.0 United States License.

This journal is published by the University Library System of the University of Pittsburgh as part of its D-Scribe Digital Publishing Program and is cosponsored by the University of Pittsburgh Press. 


\begin{tabular}{|c|c|c|c|c|c|c|c|c|c|c|}
\hline \multirow{2}{*}{ Country } & \multirow{2}{*}{$\begin{array}{c}\text { Total } \\
\text { Recovered }\end{array}$} & \multirow{2}{*}{$\begin{array}{c}\text { Total } \\
\text { deaths }\end{array}$} & \multirow{2}{*}{$\begin{array}{l}\text { Total } \\
\text { cases }\end{array}$} & \multirow{2}{*}{$\begin{array}{c}\text { Active } \\
\text { cases }\end{array}$} & \multicolumn{2}{|c|}{ Model 1} & \multicolumn{2}{|c|}{ Model 2} & \multicolumn{2}{|c|}{ Model 3} \\
\hline & & & & & CFR1 & CRR1 & CFR2 & CRR2 & CFR3 & CRR3 \\
\hline Ghana & 44,342 & 286 & 45,434 & 806 & $0.63 \%$ & $98 \%$ & $0.64 \%$ & $99.36 \%$ & $0.02 \%$ & $94.92 \%$ \\
\hline Kyrgyzstan & 40,779 & 1,063 & 44,828 & 2,986 & $2.37 \%$ & $91 \%$ & $2.54 \%$ & $97.46 \%$ & $0.62 \%$ & $89.86 \%$ \\
\hline Moldova & 30,437 & 1,117 & 42,714 & 11,160 & $2.62 \%$ & $71 \%$ & $3.54 \%$ & $96.46 \%$ & $0.32 \%$ & $69.91 \%$ \\
\hline Afghanistan & 31,234 & 1,420 & 38,641 & 5,987 & $3.67 \%$ & $81 \%$ & $4.35 \%$ & $95.65 \%$ & $0.03 \%$ & $79.89 \%$ \\
\hline Azerbaijan & 35,607 & 559 & 38,172 & 2,006 & $1.46 \%$ & $93 \%$ & $1.55 \%$ & $98.45 \%$ & $0.15 \%$ & $90.23 \%$ \\
\hline Kenya & 22,771 & 619 & 35,969 & 12,579 & $1.72 \%$ & $63 \%$ & $2.65 \%$ & $97.35 \%$ & $0.02 \%$ & $60.83 \%$ \\
\hline Czechia & 21,205 & 453 & 35,401 & 13,743 & $1.28 \%$ & $60 \%$ & $2.09 \%$ & $97.91 \%$ & $0.25 \%$ & $56.27 \%$ \\
\hline Austria & 26,579 & 754 & 32,696 & 5,363 & $2.31 \%$ & $81 \%$ & $2.76 \%$ & $97.24 \%$ & $0.09 \%$ & $78.70 \%$ \\
\hline Serbia & 31,100 & 731 & 32,300 & 469 & $2.26 \%$ & $96 \%$ & $2.30 \%$ & $97.70 \%$ & $0.03 \%$ & $91.26 \%$ \\
\hline Ireland & 23,364 & 1,783 & 30,730 & 5,583 & $5.80 \%$ & $76 \%$ & $7.09 \%$ & $92.91 \%$ & $0.19 \%$ & $73.41 \%$ \\
\hline Palestine & 19,979 & 210 & 29,906 & 9,717 & $0.70 \%$ & $67 \%$ & $1.04 \%$ & $98.96 \%$ & $0.19 \%$ & $66.07 \%$ \\
\hline Paraguay & 13,679 & 514 & 27,324 & 13,131 & $1.88 \%$ & $50 \%$ & $3.62 \%$ & $96.38 \%$ & $0.08 \%$ & $45.81 \%$ \\
\hline El Salvador & 17,874 & 782 & 26,851 & 8,195 & $2.91 \%$ & $67 \%$ & $4.19 \%$ & $95.81 \%$ & $0.19 \%$ & $65.70 \%$ \\
\hline World & $20,811,464$ & $\mathbf{9 2 4 , 5 7 7}$ & $28,943,657$ & $7,207,616$ & $3.19 \%$ & $72 \%$ & $4.25 \%$ & $95.75 \%$ & $0.73 \%$ & $68.72 \%$ \\
\hline
\end{tabular}

Table 1. The comparison of case fatality rate (CFR) and case recovery rate (CRR) by model between 72 different countries with at least 1,000 total cases. Data retrieved 13 September 2020.

\begin{tabular}{|c|c|c|c|c|c|c|c|c|c|c|c|}
\hline \multirow{2}{*}{ Continents } & \multirow{2}{*}{$\begin{array}{c}\text { Number } \\
\text { of } \\
\text { countries }\end{array}$} & \multirow{2}{*}{$\begin{array}{c}\text { Total } \\
\text { recovered }\end{array}$} & \multirow{2}{*}{$\begin{array}{c}\text { Total } \\
\text { deaths }\end{array}$} & \multirow{2}{*}{$\begin{array}{l}\text { Total } \\
\text { cases }\end{array}$} & \multirow{2}{*}{$\begin{array}{l}\text { Active } \\
\text { cases }\end{array}$} & \multicolumn{2}{|c|}{ Model 1} & \multicolumn{2}{|c|}{ Model 2} & \multicolumn{2}{|c|}{ Model 3} \\
\hline & & & & & & CFR1 & CRR1 & CFR2 & CRR2 & CFR3 & CRR3 \\
\hline Europe & 48 & $2,239,376$ & 212,327 & $4,053,217$ & $1,601,514$ & $5.24 \%$ & $55 \%$ & $8.66 \%$ & $55 \%$ & $2.47 \%$ & $47.72 \%$ \\
\hline North America & 39 & $4,835,653$ & 289,160 & $7,950,455$ & $2,825,642$ & $3.64 \%$ & $61 \%$ & $5.64 \%$ & $61 \%$ & $0.52 \%$ & $59.77 \%$ \\
\hline Asia & 49 & $6,843,427$ & 162,543 & $8,485,682$ & $1,479,712$ & $1.92 \%$ & $81 \%$ & $2.32 \%$ & $81 \%$ & $0.17 \%$ & $78.56 \%$ \\
\hline South America & 14 & $5,771,324$ & 227,166 & $7,073,893$ & $1,075,403$ & $3.21 \%$ & $82 \%$ & $3.79 \%$ & $82 \%$ & $0.05 \%$ & $81.19 \%$ \\
\hline Africa & 57 & $1,096,779$ & 32,556 & $1,352,693$ & 223,358 & $2.41 \%$ & $81 \%$ & $2.88 \%$ & $81 \%$ & $0.08 \%$ & $80.68 \%$ \\
\hline Oceania & 7 & 25,940 & 843 & 29,967 & 3,184 & $2.81 \%$ & $87 \%$ & $3.15 \%$ & $87 \%$ & $0.27 \%$ & $69.35 \%$ \\
\hline World & 210 & $20,813,150$ & 924,610 & $28,946,628$ & $7,208,868$ & $3.19 \%$ & $72 \%$ & $4.25 \%$ & $72 \%$ & $0.41 \%$ & $70.36 \%$ \\
\hline
\end{tabular}

Table 2. Continental comparison of CFRs and CRRs using three various proposed estimation methods

This work is licensed under a Creative Commons Attribution 4.0 United States License.

This journal is published by the University Library System of the University of Pittsburgh as part of its D-Scribe Digital Publishing Program and is cosponsored by the University of Pittsburgh Press. 


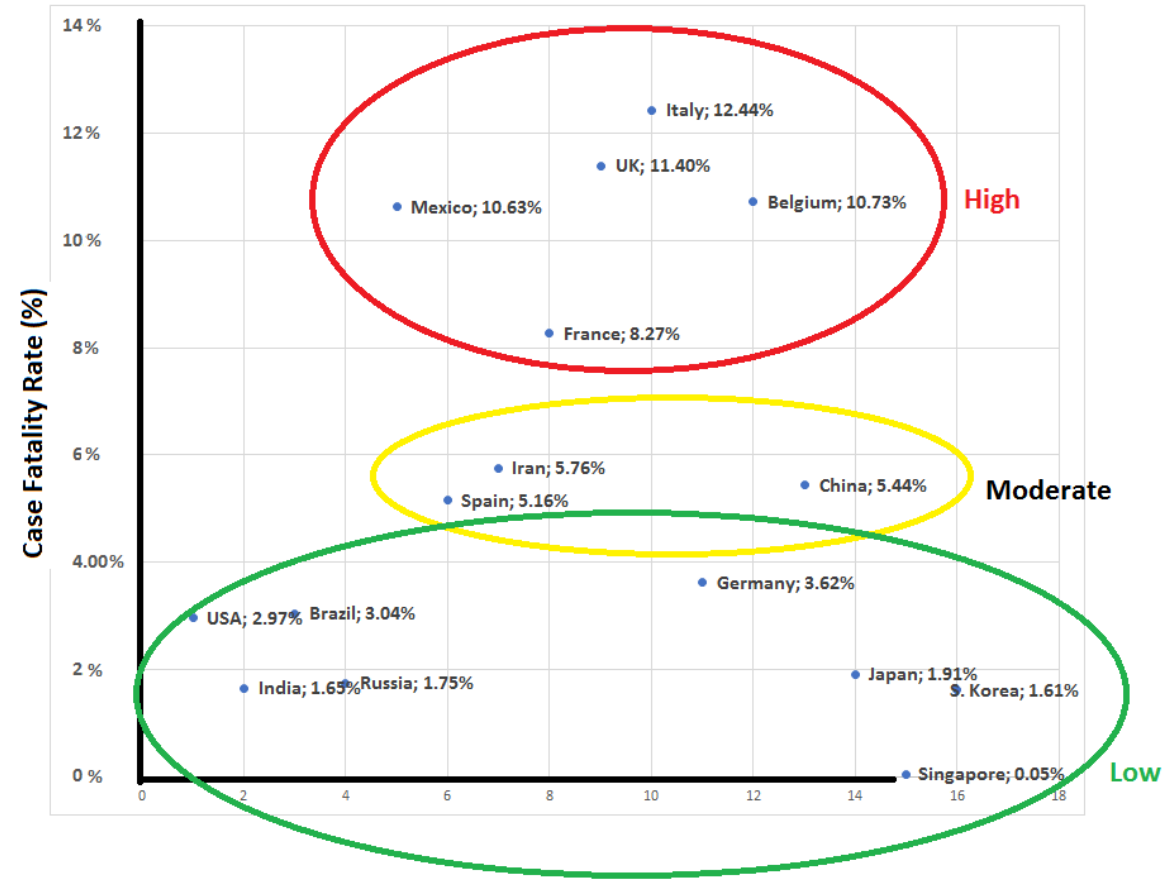

Figure 2. Comparison between countries with low, moderate, and high CFR

\begin{tabular}{lcccccc}
\hline \multirow{2}{*}{ Variables } & \multicolumn{2}{c}{ Model 1 } & \multicolumn{2}{c}{ Model 2 } & \multicolumn{2}{c}{ Model 3 } \\
\hline Population With CFR & $\boldsymbol{r}_{\boldsymbol{s}}$ & $\boldsymbol{P}$ & $\boldsymbol{r}_{\boldsymbol{s}}$ & $\boldsymbol{P}$ & $\boldsymbol{r}_{\boldsymbol{s}}$ & $\boldsymbol{P}$ \\
Population With CRR & 0.088 & 0.597 & -0.078 & 0.637 & 0.124 & 0.457 \\
GDP With CFR & 0.098 & 0.556 & 0.078 & 0.637 & -0.082 & 0.622 \\
GDP With CRR & 0.152 & 0.361 & -0.029 & 0.859 & 0.266 & 0.106 \\
NHB With CFR & 0.121 & 0.467 & 0.029 & 0.859 & 0.005 & 0.974 \\
NHB With CRR & -0.167 & 0.315 & -0.149 & 0.637 & 0.192 & 0.247 \\
NIB With CFR & 0.124 & 0.457 & 0.149 & 0.371 & 0.121 & 0.468 \\
NIB With CRR & 0.112 & 0.501 & 0.014 & 0.933 & 0.029 & 0.073 \\
Number of Ventilators With CFR & 0.122 & 0.462 & -0.014 & 0.933 & 0.217 & 0.188 \\
Number of Ventilators With CRR & -0.221 & 0.181 & -0.009 & 0.953 & 0.041 & 0.803 \\
\hline
\end{tabular}

Note: NHB: Number of Hospital Beds per 1000 people; NIB: Number of ICU Beds per 100,000 people; CFR: Case Fatality Rate; CRR: Case Recovery Rate; $r_{s}$ : Pearson Correlation Coefficient; P: P-value

Table 3. The estimated CFRs and CRRs against the county's population, GDP, number of hospital beds per 1,000 people, number of ICU beds per 100,000 people, and number of ventilators between the three different proposed models of estimation.

This work is licensed under a Creative Commons Attribution 4.0 United States License.

This journal is published by the University Library System of the University of Pittsburgh as part of its D-Scribe Digital Publishing Program and is cosponsored by the University of Pittsburgh Press. 


\begin{tabular}{|c|c|c|c|c|c|}
\hline Study ID (reference) & Country & Population & Method & CFR & $\begin{array}{c}\text { Estimation } \\
\text { level }\end{array}$ \\
\hline Change et al, 2020 (19) & China & $\begin{array}{c}>30 \text { Chinese locations and } \\
\text { other countries/regions }\end{array}$ & $\begin{array}{c}\text { Model } 1 \\
\text { (Computational using } \\
\text { Bayes Theorem) }\end{array}$ & $3.7 \%$ & Local \\
\hline Yang et al., 2020 (20) & China & $\begin{array}{l}205 \text { patients with cancer and } \\
\text { laboratory-confirmed SARS- } \\
\text { CoV-2 infection }\end{array}$ & Model 1 & $\begin{array}{c}\text { Hematological } \\
\text { malignancies: } 41 \% \\
\text { Solid tumors: } 3.28\end{array}$ & Local \\
\hline Turk et al., 2020 (21) & USA & $\begin{array}{l}474 \text { people with intellectual } \\
\text { and developmental disabilities } \\
\text { (IDD) }\end{array}$ & $\begin{array}{l}\text { Model } 1 \text { (CFR within } \\
30 \text { days) }\end{array}$ & $5.1 \%$ & Local \\
\hline Capalbo et al., 2020 (22) & Italy & $\begin{array}{c}182 \text { patients with laboratory- } \\
\text { confirmed SARS-CoV-2 } \\
\text { infection }\end{array}$ & Model 2 & $12.1 \%$ & Local \\
\hline Dongarwar and Salihu, 2020 (23) & USA & $\begin{array}{c}\text { A total of } 213 \text { countries had } \\
\text { been affected by the disease as } \\
\text { of May } 6,2020\end{array}$ & Model 1 & $\begin{array}{c}\text { Asia: } 3.5 \\
\text { Australia: } 1.4 \%\end{array}$ & Global \\
\hline Peng et al., 2020 (24) & China & $\begin{array}{l}82,836 \text { patients with COVID- } \\
19 \text { were confirmed in } \\
\text { mainland China }\end{array}$ & Model 1 & $5.6 \%$ & Local \\
\hline Abdollahi et al., 2020 (3) & $\begin{array}{l}\text { Canada } \\
\text { and } \\
\text { USA }\end{array}$ & $\begin{array}{l}\text { Using data for COVID-19 } \\
\text { confirmed cases }\end{array}$ & $\begin{array}{l}\text { Model } 1 \text { (CFR within } \\
30 \text { days) }\end{array}$ & $\begin{array}{l}\text { Canada: } 4.9 \% \\
\text { USA: } 5.4 \%\end{array}$ & Local \\
\hline Undela and Gudi, 2020 (25) & India & $2,761,121$ confirmed cases & Model 1 & $7.0 \%$ & Global \\
\hline Mi et al, 2020 (26) & China & 82,735 confirmed cases & Model 1 & $5.7 \%$ & Local \\
\hline Khafaie and Rahim, 2020 (12) & Iran & 33,570 confirmed cases & $\begin{array}{l}\text { Model } 1 \text { (CFR within } \\
30 \text { days) }\end{array}$ & 3.61 & Global \\
\hline
\end{tabular}

Table 4. Reported values and methods to calculate CFR from the literature on COVID-19

\section{Discussion}

We have presented a global consequence of COVID-19 in terms of CFRs and CRRs using three different estimation methods. By April 18, 2020, deceased cases reached 119,699 , according to data from Worldometer. ${ }^{20}$

We have shown that the CFR varies greatly geographically and even depends on the method of estimation implemented and case reports' timing. As a clear example of this, a CFR of 0.31 was estimated in Singapore and 98.82 in the UK. Even with the more precise CFR estimation method, ${ }^{4}$ we hypothesize that the value is still overestimated. Other factors that could contribute to varying estimations are the pandemic stage, number and types of tests performed, strategies of diagnostics, capability of the healthcare system, and the reporting system. For example, the USA had a significant increase in testing capacity, but the preliminary estimates of CFRs did not change dramatically (CFR=3.07 on

This work is licensed under a Creative Commons Attribution 4.0 United States License.

This journal is published by the University Library System of the University of Pittsburgh as part of its D-Scribe Digital Publishing Program and is cosponsored by the University of Pittsburgh Press. 
March 12, 2020 vs. 4.03 on April 18, 2020). ${ }^{13}$ As of April 2020, most countries were testing people with severe symptoms, mainly those needing hospitalization. The important point is that it is still unclear how many cases of COVID-19 were asymptomatic, or whether similar standards for testing are being performed between countries. Cross-country comparisons cannot be reliable indicators, unless countries are comparable or important factors are adjusted for.

However, if all these possible limitations are carefully acknowledged, CFR may help better appreciate the severity of COVID-19 and required mitigation steps. Given the impossibility of accurately estimating CFR and CRR while the COVID-19 pandemic has not yet ended, using different methods to estimate CFR and CRR, considering all possible scenarios, could help us to better estimate disease severity across different countries. Some researchers prefer to use the proportion of total deaths and recovered cases of COVID-19 disease to total disease cases at global and national levels to estimate CFRs and CRRs. After the end of the pandemic, observing CFR and CRR using this method can be done, but while the pandemic is still ongoing, this method is naïve and could be misleading.

The immune response to COVID-19 is not fully understood yet. Studies suggested the possible likelihood of relapse in recovered patients and existing models do not account for that. However, method III highly depends on the selected time period from where total cases are considered as the denominator. ${ }^{18}$ The estimation of CFR using method III $(6.22 \%)$ is similar to the method I $(8.67 \%)$. However, because all the cases have not been resolved, method III can still be assumed to be the more precise. ${ }^{18}$ Otherwise, we suggest merely extracting the active cases from the denominator while using method I. Undiagnosed cases are important for the disease spread, so detecting asymptomatic/undiagnosed cases is critical for the COVID-19 pandemic control. To this end, new methods based on mathematical models have been recently proposed to accurately calculate the health- related consequences of the COVID-19. ${ }^{21}$ One of these models is the Susceptible-Exposed-InfectiousRecovered-Dead (SEIRD) Model, which could be applied to better estimate the COVID-19 transmission rate and case fatality risk worldwide. ${ }^{22}$

CFR is used as a measure of disease severity and ideally, should be estimated by direct follow-up of cases and ascertainment of their outcome. ${ }^{23}$ We have alternatively estimated the risk in a population within a specified period by dividing the number of deaths associated with the disease by the number of cases of that disease using different methods. In this current report, we have presented risk instead of "rate" because the numerator cases were not a subset of the denominator's population. All three methods of CFR estimation have their limitations. Common limitations of the methods are the undiagnosed cases and delays in reporting data. Another limitation of this research is removing countries with a relatively small number of COVID-19 confirmed cases in the main analyses, since CFR is a flawed metric of mortality risk when the sample size is small or very limited.

CFR is commonly used to measure disease severity and is often used to predict the course or outcome of a disease. It can also be used to evaluate the effectiveness of new therapies by reducing measures and improving methods. In the COVID-19 outbreak, widespread changes in CFR estimates can be misleading, which may lead to underestimating the potential threat of COVID-19 in symptomatic patients. It is difficult to compare estimates across the countries, as different countries use different definitions and various testing strategies that may or may not include some cases. Changes in CFR may also be impacted by testing delays, dealing with delays, and differences in the quality of care or interventions at diverse stages of the disease.

Moreover, gender, ethnicity, and underlying diseases may vary by country. Cross-sectional comparisons of CFR values may be biased because the disease duration may potentially vary from country to

This work is licensed under a Creative Commons Attribution 4.0 United States License.

This journal is published by the University Library System of the University of Pittsburgh as part of its D-Scribe Digital Publishing Program and is cosponsored by the University of Pittsburgh Press.

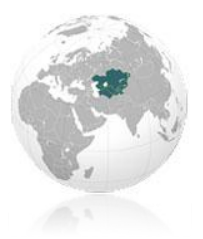


country during the epidemic. To avoid this bias, timeadjusted estimates between the onset of symptoms and death should be recommended to compare CFRs across countries. ${ }^{13}$ Therefore, the estimation of CFR in response to COVID-19 pandemic disease is a high priority, but its interpretation must be done using evidence-based strategies. Though each model has its disadvantages and pitfalls, we recommend estimating CFR using corrected model I by dividing the number of deaths on a given day by the number of patients with confirmed COVID-19 infection 14 days before, based on the assumed maximum incubation period of up to 14 days.

The WHO announced that the fatality rate of the COVID-19 is 10 times higher than that of influenza, making this research timely and relevant. ${ }^{14}$ Due to high mortality cases around the world, accurate calculations and clear estimates of CFR for COVID-19 can inform public health interventions and policies to improve health locally and globally. CFR and CRR are not the only measures of severity of the disease, and better estimators could be explored in future research.

\section{References}

1. Zhou P, Yang XL, Wang XG, et al. A pneumonia outbreak associated with a new coronavirus of probable bat origin. Nature. 2020;579(7798):270273. DOI: $10.1038 / \mathrm{s} 41586-020-2012-7$

2. Sun P, Lu X, Xu C, Sun W, Pan B. Understanding of COVID-19 based on current evidence. $J$ Med Virol. 2020. DOI: 10.1002/jmv.25722

3. Dong E, Du H, Gardner L. An interactive webbased dashboard to track COVID-19 in real time. Lancet Infect Dis. 2020;20(5):533-544. DOI: 10.1016/S1473-3099(20)30120-1

4. Abdollahi E, Champredon D, Langley JM, Galvani AP, Moghadas SM. Temporal estimates of casefatality rate for COVID-19 outbreaks in Canada and the United States. Cmaj. 2020. DOI: 10.1503/cmaj.200711

5. Kampf G, Todt D, Pfaender S, Steinmann E. Persistence of coronaviruses on inanimate surfaces and their inactivation with biocidal agents. $J$ Hosp
Infect. 2020;104(3):246-251. DOI:

10.1016/j.jhin.2020.01.022

6. Lauer SA, Grantz KH, Bi Q, et al. The Incubation Period of Coronavirus Disease 2019 (COVID-19) From Publicly Reported Confirmed Cases: Estimation and Application. Annals of Internal Medicine. 2020;172(9):577-582. DOI: 10.7326/M20-0504

7. Bulut C, Kato Y. Epidemiology of COVID-19. Turk J Med Sci. 2020;50(SI-1):563-570. DOI: 10.3906/sag-2004-172

8. Antunes JL. A dictionary in the dynamics of epidemiology. Rev Bras Epidemiol. 2016;19(1):219-223. DOI:10.1590/1980/5497201600010020

9. Rajgor DD, Lee MH, Archuleta S, Bagdasarian N, Quek SC. The many estimates of the COVID-19 case fatality rate. The Lancet Infectious Diseases. 2020;20(7):776-777. DOI: 10.1016/S14733099(20)30244-9

10. Lipsitch M, Donnelly CA, Fraser C, et al. Potential Biases in Estimating Absolute and Relative CaseFatality Risks during Outbreaks. PLoS Negl Trop Dis. 2015;9(7):e0003846. DOI: 10.1371/journal.pntd.0003846

11. Atkins KE, Wenzel NS, Ndeffo-Mbah M, Altice FL, Townsend JP, Galvani AP. Under-reporting and case fatality estimates for emerging epidemics. BMJ. 2015;350:h1115. DOI: 10.1136/bmj.h1115

12. National Academies of Sciences, Engineering, and Medicine; Health and Medicine Division; Board on Health Care Services; Committee on Health Care Utilization and Adults with Disabilities. Health-Care Utilization as a Proxy in Disability Determination. Washington (DC): National Academies Press (US); March 1, 2018.

13. Khafaie MA, Rahim F. Cross-Country Comparison of Case Fatality Rates of COVID19/SARS-COV-2. Osong Public Health Res Perspect. 2020;11(2):74-80. DOI: 10.24171/j.phrp.2020.11.2.03

14. World Health Organization (WHO). Coronavirus disease 2019 (COVID-19) Situation report-43.

This work is licensed under a Creative Commons Attribution 4.0 United States License.

This journal is published by the University Library System of the University of Pittsburgh as part of its D-Scribe Digital Publishing Program and is cosponsored by the University of Pittsburgh Press.

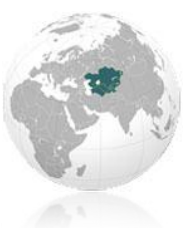


World Health Organization. March 3, 2020.

Accessed December 2020.

https://www.who.int/docs/defaultsource/coronaviruse/situation-reports/20200303sitrep-43-covid-19.pdf.

15. Centers of Disease Control and Prevention (CDC). United States COVID-19 Cases and Deaths by State. Centers for Disease Control and Prevention. 2020. Accessed March 10, 2020, https://www.cdc.gov/coronavirus/2019ncov/cases-in-us.html.

16. (US) RMAfHRaQ. Registries for Evaluating Patient Outcomes: A User's Guide [Internet]. Data Sources for Registries. 2014;

https://www.ncbi.nlm.nih.gov/books/NBK208611/

17. Battegay M, Kuehl R, Tschudin-Sutter S, Hirsch HH, Widmer AF, Neher RA. 2019-novel Coronavirus (2019-nCoV): estimating the case fatality rate - a word of caution. Swiss Med Wkly. 2020;150:w20203. DOI: 10.4414/smw.2020.20203

18. Ghani AC, Donnelly CA, Cox DR, et al. Methods for Estimating the Case Fatality Ratio for a Novel, Emerging Infectious Disease. Am J Epidemiol. 2005;162(5):479-486. DOI: 10.1093/aje/kwi230

19. Baud D, Qi X, Nielsen-Saines K, Musso D, Pomar L, Favre G. Real estimates of mortality following COVID-19 infection. The Lancet Infectious Diseases. 2020;20(7):773. DOI: 10.1016/S14733099(20)30195-X
20. COVID TC, Stephanie B, Virginia B, et al. Geographic Differences in COVID-19 Cases, Deaths, and Incidence-United States, February 12April 7, 2020. MMWR Morb Mort Wkly Rep. 2020;69(15);465-471. DOI:

10.15585/mmwr.mm6915e4

21. Li R, Pei S, Chen B, et al. Substantial undocumented infection facilitates the rapid dissemination of novel coronavirus (SARS-CoV2). Science. 2020;368(6490):489-493. DOI: 10.1126/science.abb3221

22. Maugeri A, Barchitta M, Battiato S, Agodi A. Estimation of Unreported Novel Coronavirus (SARS-CoV-2) Infections from Reported Deaths: A Susceptible-Exposed-Infectious-RecoveredDead Model. J Clin Med. 2020;9(5):1350. DOI: $10.3390 / \mathrm{jcm} 9051350$

23. Kelly H, Cowling BJ. Case Fatality: Rate, Ratio, or Risk? Epidemiology. 2013;24(4):622-623. DOI: 10.1097/EDE.0b013e318296c2b6

This work is licensed under a Creative Commons Attribution 4.0 United States License.

This journal is published by the University Library System of the University of Pittsburgh as part of its D-Scribe Digital Publishing Program and is cosponsored by the University of Pittsburgh Press.

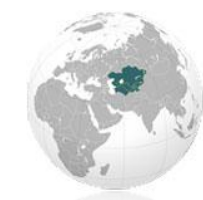


Table S1. The comparison of case fatality rate (CFR) and case recovery rate (CRR) between different countries $(n=$ 210 countries and territories around the world and 2 international conveyances). Data retrieved on September 13, 2020.

\begin{tabular}{|c|c|c|c|c|c|c|c|c|c|c|}
\hline Country & Total Recovered & Total deaths & Total cases & Active cases & CFR1 & CRR1 & CFR2 & CRR2 & CFR3 & CRR3 \\
\hline USA & $3,950,354$ & 198,128 & $6,676,601$ & $2,528,119$ & $2.97 \%$ & $59 \%$ & $4.78 \%$ & $95.22 \%$ & $0.85 \%$ & $57.09 \%$ \\
\hline India & $3,702,595$ & 78,614 & $4,754,356$ & 973,147 & $1.65 \%$ & $78 \%$ & $2.08 \%$ & $97.92 \%$ & $0.49 \%$ & $75.34 \%$ \\
\hline Brazil & $3,553,421$ & 131,274 & $4,315,858$ & 631,163 & $3.04 \%$ & $82 \%$ & $3.56 \%$ & $96.44 \%$ & $0.63 \%$ & $80.79 \%$ \\
\hline Russia & 873,535 & 18,484 & $1,057,362$ & 165,343 & $1.75 \%$ & $83 \%$ & $2.07 \%$ & $97.93 \%$ & $2.20 \%$ & $78.31 \%$ \\
\hline Peru & 559,321 & 30,593 & 722,832 & 132,918 & $4.23 \%$ & $77 \%$ & $5.19 \%$ & $94.81 \%$ & $0.85 \%$ & $61.54 \%$ \\
\hline Colombia & 592,820 & 22,734 & 708,964 & 93,410 & $3.21 \%$ & $84 \%$ & $3.69 \%$ & $96.31 \%$ & $2.98 \%$ & --- \\
\hline Mexico & 467,525 & 70,604 & 663,973 & 125,844 & $10.63 \%$ & $70 \%$ & $13.12 \%$ & $86.88 \%$ & $0.44 \%$ & $65.32 \%$ \\
\hline South Africa & 576,423 & 15,427 & 648,214 & 56,364 & $2.38 \%$ & $89 \%$ & $2.61 \%$ & $97.39 \%$ & $0.90 \%$ & $77.98 \%$ \\
\hline Spain & N/A & 29,747 & 576,697 & N/A & $5.16 \%$ & ---- & $100.00 \%$ & --- & $0.14 \%$ & ---- \\
\hline Argentina & 409,771 & 11,263 & 546,481 & 125,447 & $2.06 \%$ & $75 \%$ & $2.68 \%$ & $97.32 \%$ & $0.85 \%$ & $60.79 \%$ \\
\hline Chile & 404,919 & 11,895 & 432,666 & 15,852 & $2.75 \%$ & $94 \%$ & $2.85 \%$ & $97.15 \%$ & $1.06 \%$ & $86.39 \%$ \\
\hline Iran & 344,516 & 23,029 & 399,940 & 32,395 & $5.76 \%$ & $86 \%$ & $6.27 \%$ & $93.73 \%$ & $0.68 \%$ & $81.57 \%$ \\
\hline France & 89,059 & 30,910 & 373,911 & 253,942 & $8.27 \%$ & $24 \%$ & $25.76 \%$ & $74.24 \%$ & $1.93 \%$ & $20.91 \%$ \\
\hline UK & N/A & 41,623 & 365,174 & N/A & $11.40 \%$ & ---- & $100.00 \%$ & --- & $1.24 \%$ & --- \\
\hline Bangladesh & 238,271 & 4,702 & 336,044 & 93,071 & $1.40 \%$ & $71 \%$ & $1.94 \%$ & $98.06 \%$ & $0.28 \%$ & $68.78 \%$ \\
\hline Saudi Arabia & 301,836 & 4,240 & 325,050 & 18,974 & $1.30 \%$ & $93 \%$ & $1.39 \%$ & $98.61 \%$ & $0.51 \%$ & $86.03 \%$ \\
\hline Pakistan & 289,429 & 6,379 & 301,481 & 5,673 & $2.12 \%$ & $96 \%$ & $2.16 \%$ & $97.84 \%$ & $0.26 \%$ & $93.21 \%$ \\
\hline Turkey & 257,731 & 6,999 & 289,635 & 24,905 & $2.42 \%$ & $89 \%$ & $2.64 \%$ & $97.36 \%$ & $0.32 \%$ & $88.52 \%$ \\
\hline Iraq & 221,283 & 7,941 & 286,778 & 57,554 & $2.77 \%$ & $77 \%$ & $3.46 \%$ & $96.54 \%$ & $0.23 \%$ & $76.62 \%$ \\
\hline Italy & 213,191 & 35,603 & 286,297 & 37,503 & $12.44 \%$ & $74 \%$ & $14.31 \%$ & $85.69 \%$ & $0.38 \%$ & $71.24 \%$ \\
\hline Germany & 235,300 & 9,427 & 260,546 & 15,819 & $3.62 \%$ & $90 \%$ & $3.85 \%$ & $96.15 \%$ & $0.87 \%$ & $89.92 \%$ \\
\hline Philippines & 187,116 & 4,292 & 257,863 & 66,455 & $1.66 \%$ & $73 \%$ & $2.24 \%$ & $97.76 \%$ & $0.06 \%$ & $71.58 \%$ \\
\hline Indonesia & 152,458 & 8,650 & 214,746 & 53,638 & $4.03 \%$ & $71 \%$ & $5.37 \%$ & $94.63 \%$ & $0.09 \%$ & $67.64 \%$ \\
\hline Israel & 113,496 & 1,103 & 152,722 & 38,123 & $0.72 \%$ & $74 \%$ & $0.96 \%$ & $99.04 \%$ & $0.94 \%$ & $68.37 \%$ \\
\hline Ukraine & 68,346 & 3,148 & 151,859 & 80,365 & $2.07 \%$ & $45 \%$ & $4.40 \%$ & $95.60 \%$ & $0.36 \%$ & $36.87 \%$ \\
\hline Canada & 120,075 & 9,170 & 136,141 & 6,896 & $6.74 \%$ & $88 \%$ & $7.10 \%$ & $92.90 \%$ & $0.01 \%$ & $87.39 \%$ \\
\hline Bolivia & 82,796 & 7,297 & 125,982 & 35,889 & $5.79 \%$ & $66 \%$ & $8.10 \%$ & $91.90 \%$ & $0.23 \%$ & $63.32 \%$ \\
\hline Qatar & 118,475 & 205 & 121,523 & 2,843 & $0.17 \%$ & $97 \%$ & $0.17 \%$ & $99.83 \%$ & $0.16 \%$ & $91.46 \%$ \\
\hline Ecuador & 91,242 & 10,864 & 116,451 & 14,345 & $9.33 \%$ & $78 \%$ & $10.64 \%$ & $89.36 \%$ & $0.33 \%$ & $76.72 \%$ \\
\hline Kazakhstan & 100,615 & 1,634 & 106,803 & 4,554 & $1.53 \%$ & $94 \%$ & $1.60 \%$ & $98.40 \%$ & $0.53 \%$ & $91.90 \%$ \\
\hline Dominican Republic & 76,531 & 1,953 & 103,092 & 24,608 & $1.89 \%$ & $74 \%$ & $2.49 \%$ & $97.51 \%$ & $0.62 \%$ & $71.19 \%$ \\
\hline Romania & 42,811 & 4,127 & 102,386 & 55,448 & $4.03 \%$ & $42 \%$ & $8.79 \%$ & $91.21 \%$ & $0.07 \%$ & $40.11 \%$ \\
\hline Panama & 73,476 & 2,155 & 101,041 & 25,410 & $2.13 \%$ & $73 \%$ & $2.85 \%$ & $97.15 \%$ & $0.01 \%$ & $71.66 \%$ \\
\hline Egypt & 83,261 & 5,627 & 100,856 & 11,968 & $5.58 \%$ & $83 \%$ & $6.33 \%$ & $93.67 \%$ & $0.08 \%$ & $80.48 \%$ \\
\hline Kuwait & 84,404 & 558 & 94,211 & 9,249 & $0.59 \%$ & $90 \%$ & $0.66 \%$ & $99.34 \%$ & $0.26 \%$ & $80.19 \%$ \\
\hline Belgium & 18,709 & 9,923 & 92,478 & 63,846 & $10.73 \%$ & $20 \%$ & $34.66 \%$ & $65.34 \%$ & $0.83 \%$ & $18.99 \%$ \\
\hline Oman & 83,325 & 762 & 88,337 & 4,250 & $0.86 \%$ & $94 \%$ & $0.91 \%$ & $99.09 \%$ & $0.25 \%$ & $93.35 \%$ \\
\hline Sweden & N/A & 5,846 & 86,505 & N/A & $6.76 \%$ & ---- & $100.00 \%$ & --- & $0.49 \%$ & --- \\
\hline China & 80,399 & 4,634 & 85,184 & 151 & $5.44 \%$ & $94 \%$ & $5.45 \%$ & $94.55 \%$ & $0.19 \%$ & $92.96 \%$ \\
\hline Morocco & 65,867 & 1,553 & 84,435 & 17,015 & $1.84 \%$ & $78 \%$ & $2.30 \%$ & $97.70 \%$ & $0.61 \%$ & $76.91 \%$ \\
\hline Guatemala & 70,403 & 2,949 & 81,658 & 8,306 & $3.61 \%$ & $86 \%$ & $4.02 \%$ & $95.98 \%$ & $0.25 \%$ & $86.18 \%$ \\
\hline
\end{tabular}

This work is licensed under a Creative Commons Attribution 4.0 United States License.

This journal is published by the University Library System of the University of Pittsburgh as part of its D-Scribe Digital Publishing Program and is cosponsored by the University of Pittsburgh Press. 


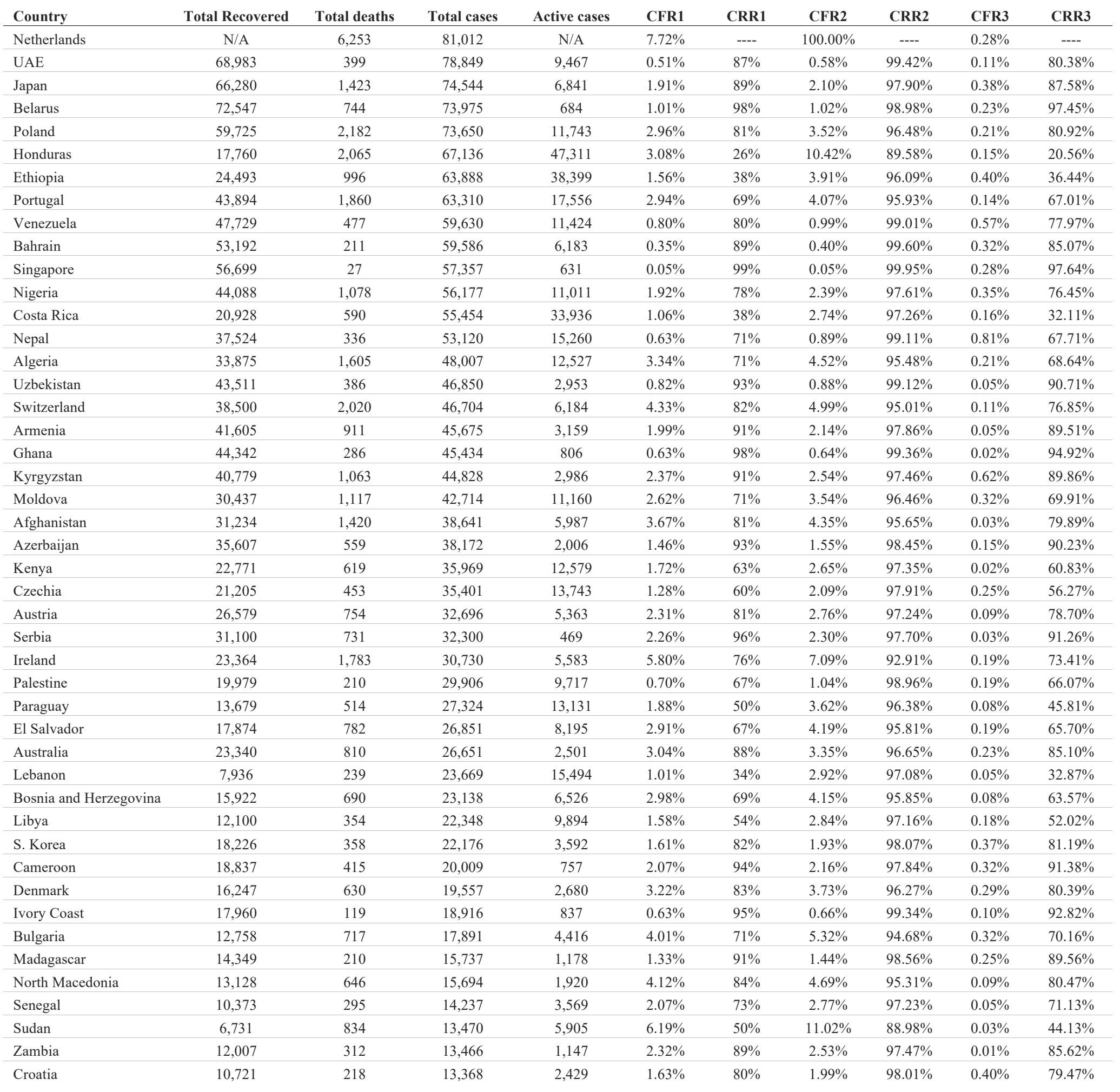

This work is licensed under a Creative Commons Attribution 4.0 United States License.

This journal is published by the University Library System of the University of Pittsburgh as part of its D-Scribe Digital Publishing Program and is cosponsored by the University of Pittsburgh Press. 


\begin{tabular}{|c|c|c|c|c|c|c|c|c|c|c|}
\hline Country & Total Recovered & Total deaths & Total cases & Active cases & CFR1 & CRR1 & CFR2 & CRR2 & CFR3 & CRR3 \\
\hline Greece & 3,804 & 302 & 13,036 & 8,930 & $2.32 \%$ & $29 \%$ & $7.36 \%$ & $92.64 \%$ & $0.30 \%$ & $27.04 \%$ \\
\hline Norway & 10,371 & 265 & 12,079 & 1,443 & $2.19 \%$ & $86 \%$ & $2.49 \%$ & $97.51 \%$ & $0.12 \%$ & $84.63 \%$ \\
\hline Hungary & 4,058 & 633 & 11,825 & 7,134 & $5.35 \%$ & $34 \%$ & $13.49 \%$ & $86.51 \%$ & $0.11 \%$ & $32.06 \%$ \\
\hline Albania & 6,494 & 330 & 11,185 & 4,361 & $2.95 \%$ & $58 \%$ & $4.84 \%$ & $95.16 \%$ & $0.36 \%$ & $54.62 \%$ \\
\hline DRC & 9,719 & 262 & 10,385 & 404 & $2.52 \%$ & $94 \%$ & $2.62 \%$ & $97.38 \%$ & $0.27 \%$ & $89.52 \%$ \\
\hline Guinea & 9,251 & 63 & 10,020 & 706 & $0.63 \%$ & $92 \%$ & $0.68 \%$ & $99.32 \%$ & $0.09 \%$ & $89.49 \%$ \\
\hline Malaysia & 9,189 & 128 & 9,868 & 551 & $1.30 \%$ & $93 \%$ & $1.37 \%$ & $98.63 \%$ & $0.13 \%$ & $86.58 \%$ \\
\hline Namibia & 5,811 & 98 & 9,604 & 3,695 & $1.02 \%$ & $61 \%$ & $1.66 \%$ & $98.34 \%$ & $0.25 \%$ & $59.00 \%$ \\
\hline French Guiana & 9,132 & 63 & 9,521 & 326 & $0.66 \%$ & $96 \%$ & $0.69 \%$ & $99.31 \%$ & $0.30 \%$ & $91.87 \%$ \\
\hline Maldives & 7,055 & 31 & 9,052 & 1,966 & $0.34 \%$ & $78 \%$ & $0.44 \%$ & $99.56 \%$ & $0.07 \%$ & $74.77 \%$ \\
\hline Tajikistan & 7,782 & 72 & 9,014 & 1,160 & $0.80 \%$ & $86 \%$ & $0.92 \%$ & $99.08 \%$ & $0.09 \%$ & $81.95 \%$ \\
\hline Gabon & 7,706 & 53 & 8,643 & 884 & $0.61 \%$ & $89 \%$ & $0.68 \%$ & $99.32 \%$ & $0.71 \%$ & $88.24 \%$ \\
\hline Finland & 7,500 & 337 & 8,557 & 720 & $3.94 \%$ & $88 \%$ & $4.30 \%$ & $95.70 \%$ & $0.49 \%$ & $82.17 \%$ \\
\hline Haiti & 6,120 & 219 & 8,478 & 2,139 & $2.58 \%$ & $72 \%$ & $3.45 \%$ & $96.55 \%$ & $0.18 \%$ & $67.63 \%$ \\
\hline Zimbabwe & 5,675 & 224 & 7,508 & 1,609 & $2.98 \%$ & $76 \%$ & $3.80 \%$ & $96.20 \%$ & $0.09 \%$ & $73.91 \%$ \\
\hline Mauritania & 6,804 & 161 & 7,274 & 309 & $2.21 \%$ & $94 \%$ & $2.31 \%$ & $97.69 \%$ & $0.56 \%$ & $92.66 \%$ \\
\hline Luxembourg & 6,397 & 124 & 7,194 & 673 & $1.72 \%$ & $89 \%$ & $1.90 \%$ & $98.10 \%$ & $0.21 \%$ & $88.24 \%$ \\
\hline Tunisia & 1,991 & 107 & 6,635 & 4,537 & $1.61 \%$ & $30 \%$ & $5.10 \%$ & $94.90 \%$ & $0.53 \%$ & $24.70 \%$ \\
\hline Montenegro & 4,491 & 118 & 6,530 & 1,921 & $1.81 \%$ & $69 \%$ & $2.56 \%$ & $97.44 \%$ & $0.09 \%$ & $66.39 \%$ \\
\hline Malawi & 3,724 & 177 & 5,678 & 1,777 & $3.12 \%$ & $66 \%$ & $4.54 \%$ & $95.46 \%$ & $0.46 \%$ & $65.41 \%$ \\
\hline Slovakia & 3,114 & 38 & 5,453 & 2,301 & $0.70 \%$ & $57 \%$ & $1.21 \%$ & $98.79 \%$ & $0.51 \%$ & $56.19 \%$ \\
\hline Djibouti & 5,327 & 61 & 5,394 & 6 & $1.13 \%$ & $99 \%$ & $1.13 \%$ & $98.87 \%$ & $0.07 \%$ & $93.46 \%$ \\
\hline Eswatini & 4,188 & 98 & 5,050 & 764 & $1.94 \%$ & $83 \%$ & $2.29 \%$ & $97.71 \%$ & $0.14 \%$ & $76.16 \%$ \\
\hline Mozambique & 2,905 & 35 & 5,040 & 2,100 & $0.69 \%$ & $58 \%$ & $1.19 \%$ & $98.81 \%$ & $0.12 \%$ & $51.88 \%$ \\
\hline Equatorial Guinea & 4,490 & 83 & 4,996 & 423 & $1.66 \%$ & $90 \%$ & $1.82 \%$ & $98.18 \%$ & $0.00 \%$ & $83.87 \%$ \\
\hline Hong Kong & 4,613 & 100 & 4,939 & 226 & $2.02 \%$ & $93 \%$ & $2.12 \%$ & $97.88 \%$ & $0.47 \%$ & $91.11 \%$ \\
\hline Congo & 3,887 & 88 & 4,928 & 953 & $1.79 \%$ & $79 \%$ & $2.21 \%$ & $97.79 \%$ & $0.08 \%$ & $75.95 \%$ \\
\hline Nicaragua & 2,913 & 144 & 4,818 & 1,761 & $2.99 \%$ & $60 \%$ & $4.71 \%$ & $95.29 \%$ & $0.15 \%$ & $59.86 \%$ \\
\hline CAR & 1,825 & 62 & 4,749 & 2,862 & $1.31 \%$ & $38 \%$ & $3.29 \%$ & $96.71 \%$ & $0.29 \%$ & $36.03 \%$ \\
\hline Cabo Verde & 4,104 & 44 & 4,711 & 563 & $0.93 \%$ & $87 \%$ & $1.06 \%$ & $98.94 \%$ & $0.04 \%$ & $85.35 \%$ \\
\hline Uganda & 1,998 & 52 & 4,703 & 2,653 & $1.11 \%$ & $42 \%$ & $2.54 \%$ & $97.46 \%$ & $0.21 \%$ & $36.06 \%$ \\
\hline Cuba & 3,878 & 108 & 4,653 & 667 & $2.32 \%$ & $83 \%$ & $2.71 \%$ & $97.29 \%$ & $0.21 \%$ & $80.29 \%$ \\
\hline Suriname & 3,788 & 93 & 4,579 & 698 & $2.03 \%$ & $83 \%$ & $2.40 \%$ & $97.60 \%$ & $0.17 \%$ & $80.78 \%$ \\
\hline Rwanda & 2,544 & 22 & 4,565 & 1,999 & $0.48 \%$ & $56 \%$ & $0.86 \%$ & $99.14 \%$ & $0.15 \%$ & $51.59 \%$ \\
\hline Jamaica & 1,072 & 40 & 3,623 & 2,511 & $1.10 \%$ & $30 \%$ & $3.60 \%$ & $96.40 \%$ & $0.55 \%$ & $22.74 \%$ \\
\hline Slovenia & 2,699 & 135 & 3,603 & 769 & $3.75 \%$ & $75 \%$ & $4.76 \%$ & $95.24 \%$ & $0.28 \%$ & $73.58 \%$ \\
\hline Syria & 827 & 152 & 3,506 & 2,527 & $4.34 \%$ & $24 \%$ & $15.53 \%$ & $84.47 \%$ & $0.63 \%$ & $22.99 \%$ \\
\hline Thailand & 3,312 & 58 & 3,473 & 103 & $1.67 \%$ & $95 \%$ & $1.72 \%$ & $98.28 \%$ & $0.00 \%$ & $88.89 \%$ \\
\hline Gambia & 1,617 & 102 & 3,376 & 1,657 & $3.02 \%$ & $48 \%$ & $5.93 \%$ & $94.07 \%$ & $0.03 \%$ & $47.63 \%$ \\
\hline Somalia & 2,791 & 98 & 3,376 & 487 & $2.90 \%$ & $83 \%$ & $3.39 \%$ & $96.61 \%$ & $0.27 \%$ & $79.86 \%$ \\
\hline Mayotte & 2,964 & 40 & 3,374 & 370 & $1.19 \%$ & $88 \%$ & $1.33 \%$ & $98.67 \%$ & $0.00 \%$ & $87.34 \%$ \\
\hline Angola & 1,289 & 132 & 3,335 & 1,914 & $3.96 \%$ & $39 \%$ & $9.29 \%$ & $90.71 \%$ & $0.09 \%$ & $37.36 \%$ \\
\hline Lithuania & 2,070 & 86 & 3,296 & 1,140 & $2.61 \%$ & $63 \%$ & $3.99 \%$ & $96.01 \%$ & $0.24 \%$ & $62.23 \%$ \\
\hline Sri Lanka & 2,983 & 12 & 3,195 & 200 & $0.38 \%$ & $93 \%$ & $0.40 \%$ & $99.60 \%$ & $0.00 \%$ & $90.45 \%$ \\
\hline Guadeloupe & 837 & 24 & 3,080 & 2,219 & $0.78 \%$ & $27 \%$ & $2.79 \%$ & $97.21 \%$ & $0.00 \%$ & $21.40 \%$ \\
\hline Jordan & 2,156 & 22 & 3,062 & 884 & $0.72 \%$ & $70 \%$ & $1.01 \%$ & $98.99 \%$ & $0.46 \%$ & $67.90 \%$ \\
\hline
\end{tabular}

This work is licensed under a Creative Commons Attribution 4.0 United States License.

This journal is published by the University Library System of the University of Pittsburgh as part of its D-Scribe Digital Publishing Program and is cosponsored by the University of Pittsburgh Press. 


\begin{tabular}{|c|c|c|c|c|c|c|c|c|c|c|}
\hline Country & Total Recovered & Total deaths & Total cases & Active cases & CFR1 & CRR1 & CFR2 & CRR2 & CFR3 & CRR3 \\
\hline Aruba & 1,542 & 18 & 2,994 & 1,434 & $0.60 \%$ & $52 \%$ & $1.15 \%$ & $98.85 \%$ & $0.40 \%$ & $48.76 \%$ \\
\hline Trinidad and Tobago & 766 & 51 & 2,993 & 2,176 & $1.70 \%$ & $26 \%$ & $6.24 \%$ & $93.76 \%$ & $0.17 \%$ & $25.06 \%$ \\
\hline Bahamas & 1,319 & 67 & 2,928 & 1,542 & $2.29 \%$ & $45 \%$ & $4.83 \%$ & $95.17 \%$ & $0.00 \%$ & $40.57 \%$ \\
\hline Mali & 2,276 & 128 & 2,916 & 512 & $4.39 \%$ & $78 \%$ & $5.32 \%$ & $94.68 \%$ & $0.03 \%$ & $73.80 \%$ \\
\hline Myanmar & 676 & 16 & 2,796 & 2,104 & $0.57 \%$ & $24 \%$ & $2.31 \%$ & $97.69 \%$ & $0.57 \%$ & $23.28 \%$ \\
\hline Réunion & 1,313 & 14 & 2,723 & 1,396 & $0.51 \%$ & $48 \%$ & $1.06 \%$ & $98.94 \%$ & $0.00 \%$ & $45.46 \%$ \\
\hline Estonia & 2,252 & 64 & 2,655 & 339 & $2.41 \%$ & $85 \%$ & $2.76 \%$ & $97.24 \%$ & $0.11 \%$ & $82.94 \%$ \\
\hline South Sudan & 1,290 & 49 & 2,578 & 1,239 & $1.90 \%$ & $50 \%$ & $3.66 \%$ & $96.34 \%$ & $0.00 \%$ & $45.42 \%$ \\
\hline Guinea-Bissau & 1,127 & 39 & 2,275 & 1,109 & $1.71 \%$ & $50 \%$ & $3.34 \%$ & $96.66 \%$ & $0.35 \%$ & $46.95 \%$ \\
\hline Malta & 1,850 & 15 & 2,274 & 409 & $0.66 \%$ & $81 \%$ & $0.80 \%$ & $99.20 \%$ & $0.04 \%$ & $77.53 \%$ \\
\hline Botswana & 546 & 10 & 2,252 & 1,696 & $0.44 \%$ & $24 \%$ & $1.80 \%$ & $98.20 \%$ & $0.27 \%$ & $22.29 \%$ \\
\hline Benin & 1,793 & 40 & 2,242 & 409 & $1.78 \%$ & $80 \%$ & $2.18 \%$ & $97.82 \%$ & $0.04 \%$ & $79.93 \%$ \\
\hline Iceland & 2,085 & 10 & 2,162 & 67 & $0.46 \%$ & $96 \%$ & $0.48 \%$ & $99.52 \%$ & $0.09 \%$ & $93.06 \%$ \\
\hline Sierra Leone & 1,634 & 72 & 2,096 & 390 & $3.44 \%$ & $78 \%$ & $4.22 \%$ & $95.78 \%$ & $0.29 \%$ & $75.00 \%$ \\
\hline Georgia & 1,363 & 19 & 2,075 & 693 & $0.92 \%$ & $66 \%$ & $1.37 \%$ & $98.63 \%$ & $0.19 \%$ & $63.66 \%$ \\
\hline Yemen & 1,211 & 582 & 2,009 & 216 & $28.97 \%$ & $60 \%$ & $32.46 \%$ & $67.54 \%$ & $0.20 \%$ & $59.78 \%$ \\
\hline Guyana & 1,191 & 54 & 1,812 & 567 & $2.98 \%$ & $66 \%$ & $4.34 \%$ & $95.66 \%$ & $0.17 \%$ & $63.41 \%$ \\
\hline New Zealand & 1,676 & 24 & 1,797 & 97 & $1.34 \%$ & $93 \%$ & $1.41 \%$ & $98.59 \%$ & $0.06 \%$ & $90.21 \%$ \\
\hline Uruguay & 1,502 & 45 & 1,780 & 233 & $2.53 \%$ & $84 \%$ & $2.91 \%$ & $97.09 \%$ & $0.62 \%$ & $83.15 \%$ \\
\hline Togo & 1,189 & 37 & 1,555 & 329 & $2.38 \%$ & $76 \%$ & $3.02 \%$ & $96.98 \%$ & $0.39 \%$ & $73.95 \%$ \\
\hline Cyprus & 1,281 & 22 & 1,523 & 220 & $1.44 \%$ & $84 \%$ & $1.69 \%$ & $98.31 \%$ & $0.00 \%$ & $81.02 \%$ \\
\hline Burkina Faso & 1,127 & 56 & 1,514 & 331 & $3.70 \%$ & $74 \%$ & $4.73 \%$ & $95.27 \%$ & $0.40 \%$ & $73.91 \%$ \\
\hline Latvia & 1,248 & 35 & 1,464 & 181 & $2.39 \%$ & $85 \%$ & $2.73 \%$ & $97.27 \%$ & $0.00 \%$ & $84.43 \%$ \\
\hline Belize & 458 & 19 & 1,458 & 981 & $1.30 \%$ & $31 \%$ & $3.98 \%$ & $96.02 \%$ & $0.89 \%$ & $29.15 \%$ \\
\hline Andorra & 943 & 53 & 1,344 & 348 & $3.94 \%$ & $70 \%$ & $5.32 \%$ & $94.68 \%$ & $0.60 \%$ & $69.05 \%$ \\
\hline Liberia & 1,210 & 82 & 1,316 & 24 & $6.23 \%$ & $92 \%$ & $6.35 \%$ & $93.65 \%$ & $0.08 \%$ & $90.58 \%$ \\
\hline Lesotho & 528 & 33 & 1,245 & 684 & $2.65 \%$ & $42 \%$ & $5.88 \%$ & $94.12 \%$ & $0.08 \%$ & $41.77 \%$ \\
\hline Niger & 1,100 & 69 & 1,178 & 9 & $5.86 \%$ & $93 \%$ & $5.90 \%$ & $94.10 \%$ & $0.08 \%$ & $92.53 \%$ \\
\hline Chad & 938 & 80 & 1,083 & 65 & $7.39 \%$ & $87 \%$ & $7.86 \%$ & $92.14 \%$ & $0.09 \%$ & $83.56 \%$ \\
\hline Vietnam & 910 & 35 & 1,060 & 115 & $3.30 \%$ & $86 \%$ & $3.70 \%$ & $96.30 \%$ & $0.19 \%$ & $84.15 \%$ \\
\hline French Polynesia & 642 & 2 & 953 & 309 & $0.21 \%$ & $67 \%$ & $0.31 \%$ & $99.69 \%$ & $0.00 \%$ & $62.85 \%$ \\
\hline Martinique & 98 & 18 & 939 & 823 & $1.92 \%$ & $10 \%$ & $15.52 \%$ & $84.48 \%$ & $0.00 \%$ & $8.73 \%$ \\
\hline Sao Tome and Principe & 866 & 15 & 906 & 25 & $1.66 \%$ & $96 \%$ & $1.70 \%$ & $98.30 \%$ & $0.00 \%$ & $93.93 \%$ \\
\hline San Marino & 662 & 42 & 722 & 18 & $5.82 \%$ & $92 \%$ & $5.97 \%$ & $94.03 \%$ & $0.00 \%$ & $87.26 \%$ \\
\hline Diamond Princess & 651 & 13 & 712 & 48 & $1.83 \%$ & $91 \%$ & $1.96 \%$ & $98.04 \%$ & $0.42 \%$ & $88.76 \%$ \\
\hline Turks and Caicos & 270 & 5 & 641 & 366 & $0.78 \%$ & $42 \%$ & $1.82 \%$ & $98.18 \%$ & $0.00 \%$ & $40.09 \%$ \\
\hline Channel Islands & 575 & 48 & 633 & 10 & $7.58 \%$ & $91 \%$ & $7.70 \%$ & $92.30 \%$ & $0.47 \%$ & $87.05 \%$ \\
\hline Sint Maarten & 430 & 19 & 533 & 84 & $3.56 \%$ & $81 \%$ & $4.23 \%$ & $95.77 \%$ & $0.00 \%$ & $78.80 \%$ \\
\hline Tanzania & 183 & 21 & 509 & 305 & $4.13 \%$ & $36 \%$ & $10.29 \%$ & $89.71 \%$ & $0.59 \%$ & $35.17 \%$ \\
\hline Papua New Guinea & 232 & 5 & 508 & 271 & $0.98 \%$ & $46 \%$ & $2.11 \%$ & $97.89 \%$ & $0.79 \%$ & $44.69 \%$ \\
\hline Taiwan & 475 & 7 & 498 & 16 & $1.41 \%$ & $95 \%$ & $1.45 \%$ & $98.55 \%$ & $0.40 \%$ & $94.18 \%$ \\
\hline Burundi & 374 & 1 & 471 & 96 & $0.21 \%$ & $79 \%$ & $0.27 \%$ & $99.73 \%$ & $0.64 \%$ & $77.07 \%$ \\
\hline Comoros & 415 & 7 & 456 & 34 & $1.54 \%$ & $91 \%$ & $1.66 \%$ & $98.34 \%$ & $0.00 \%$ & $90.57 \%$ \\
\hline Faeroe Islands & 410 & & 418 & 8 & $0.00 \%$ & $98 \%$ & $0.00 \%$ & $100.00 \%$ & $0.24 \%$ & $98.09 \%$ \\
\hline Mauritius & 335 & 10 & 361 & 16 & $2.77 \%$ & $93 \%$ & $2.90 \%$ & $97.10 \%$ & $0.00 \%$ & $90.03 \%$ \\
\hline Eritrea & 304 & & 361 & 57 & $0.00 \%$ & $84 \%$ & $0.00 \%$ & $100.00 \%$ & $0.00 \%$ & $82.27 \%$ \\
\hline
\end{tabular}

This work is licensed under a Creative Commons Attribution 4.0 United States License.

This journal is published by the University Library System of the University of Pittsburgh as part of its D-Scribe Digital Publishing Program and is cosponsored by the University of Pittsburgh Press. 


\begin{tabular}{|c|c|c|c|c|c|c|c|c|c|c|}
\hline Country & Total Recovered & Total deaths & Total cases & Active cases & CFR1 & CRR1 & CFR2 & CRR2 & CFR3 & CRR3 \\
\hline Isle of Man & 312 & 24 & 337 & 1 & $7.12 \%$ & $93 \%$ & $7.14 \%$ & $92.86 \%$ & $0.59 \%$ & $90.80 \%$ \\
\hline Gibraltar & 294 & & 327 & 33 & $0.00 \%$ & $90 \%$ & $0.00 \%$ & $100.00 \%$ & $0.00 \%$ & $86.24 \%$ \\
\hline Mongolia & 298 & & 311 & 13 & $0.00 \%$ & $96 \%$ & $0.00 \%$ & $100.00 \%$ & $0.00 \%$ & $93.57 \%$ \\
\hline Cambodia & 274 & & 275 & 1 & $0.00 \%$ & $100 \%$ & $0.00 \%$ & $100.00 \%$ & $0.00 \%$ & $93.45 \%$ \\
\hline Saint Martin & 107 & 6 & 256 & 143 & $2.34 \%$ & $42 \%$ & $5.31 \%$ & $94.69 \%$ & $0.39 \%$ & $37.50 \%$ \\
\hline Bhutan & 159 & & 244 & 85 & $0.00 \%$ & $65 \%$ & $0.00 \%$ & $100.00 \%$ & $0.00 \%$ & $59.84 \%$ \\
\hline Cayman Islands & 204 & 1 & 208 & 3 & $0.48 \%$ & $98 \%$ & $0.49 \%$ & $99.51 \%$ & $0.00 \%$ & $94.23 \%$ \\
\hline Bermuda & 161 & 9 & 177 & 7 & $5.08 \%$ & $91 \%$ & $5.29 \%$ & $94.71 \%$ & $0.00 \%$ & $82.49 \%$ \\
\hline Monaco & 123 & 1 & 169 & 45 & $0.59 \%$ & $73 \%$ & $0.81 \%$ & $99.19 \%$ & $0.00 \%$ & $68.05 \%$ \\
\hline Brunei & 139 & 3 & 145 & 3 & $2.07 \%$ & $96 \%$ & $2.11 \%$ & $97.89 \%$ & $2.07 \%$ & $91.03 \%$ \\
\hline Curaçao & 56 & 1 & 145 & 88 & $0.69 \%$ & $39 \%$ & $1.75 \%$ & $98.25 \%$ & $0.00 \%$ & $31.03 \%$ \\
\hline Seychelles & 136 & & 139 & 3 & $0.00 \%$ & $98 \%$ & $0.00 \%$ & $100.00 \%$ & $0.72 \%$ & $94.24 \%$ \\
\hline Liechtenstein & 105 & 1 & 111 & 5 & $0.90 \%$ & $95 \%$ & $0.94 \%$ & $99.06 \%$ & $0.90 \%$ & $90.99 \%$ \\
\hline Antigua and Barbuda & 91 & 3 & 95 & 1 & $3.16 \%$ & $96 \%$ & $3.19 \%$ & $96.81 \%$ & $1.05 \%$ & $93.68 \%$ \\
\hline St. Vincent Grenadines & 61 & & 64 & 3 & $0.00 \%$ & $95 \%$ & $0.00 \%$ & $100.00 \%$ & $0.00 \%$ & $85.94 \%$ \\
\hline Macao & 46 & & 46 & 0 & $0.00 \%$ & $100 \%$ & $0.00 \%$ & $100.00 \%$ & $2.17 \%$ & $82.61 \%$ \\
\hline Fiji & 24 & 2 & 32 & 6 & $6.25 \%$ & $75 \%$ & $7.69 \%$ & $92.31 \%$ & $3.13 \%$ & $53.13 \%$ \\
\hline Saint Lucia & 26 & & 27 & 1 & $0.00 \%$ & $96 \%$ & $0.00 \%$ & $100.00 \%$ & $7.41 \%$ & $96.30 \%$ \\
\hline Timor-Leste & 25 & & 27 & 2 & $0.00 \%$ & $93 \%$ & $0.00 \%$ & $100.00 \%$ & $0.00 \%$ & $85.19 \%$ \\
\hline New Caledonia & 26 & & 26 & 0 & $0.00 \%$ & $100 \%$ & $0.00 \%$ & $100.00 \%$ & $0.00 \%$ & $100.00 \%$ \\
\hline Caribbean Netherlands & 7 & & 25 & 18 & $0.00 \%$ & $28 \%$ & $0.00 \%$ & $100.00 \%$ & $4.00 \%$ & $4.00 \%$ \\
\hline Dominica & 18 & & 24 & 6 & $0.00 \%$ & $75 \%$ & $0.00 \%$ & $100.00 \%$ & $0.00 \%$ & $58.33 \%$ \\
\hline Grenada & 24 & & 24 & 0 & $0.00 \%$ & $100 \%$ & $0.00 \%$ & $100.00 \%$ & $4.17 \%$ & $87.50 \%$ \\
\hline Laos & 21 & & 23 & 2 & $0.00 \%$ & $91 \%$ & $0.00 \%$ & $100.00 \%$ & $0.00 \%$ & $65.22 \%$ \\
\hline St. Barth & 13 & & 21 & 8 & $0.00 \%$ & $62 \%$ & $0.00 \%$ & $100.00 \%$ & $0.00 \%$ & $61.90 \%$ \\
\hline Saint Kitts and Nevis & 17 & & 17 & 0 & $0.00 \%$ & $100 \%$ & $0.00 \%$ & $100.00 \%$ & $0.00 \%$ & $70.59 \%$ \\
\hline Greenland & 14 & & 14 & 0 & $0.00 \%$ & $100 \%$ & $0.00 \%$ & $100.00 \%$ & $0.00 \%$ & $100.00 \%$ \\
\hline Montserrat & 11 & 1 & 13 & 1 & $7.69 \%$ & $85 \%$ & $8.33 \%$ & $91.67 \%$ & $0.00 \%$ & $84.62 \%$ \\
\hline Falkland Islands & 13 & & 13 & 0 & $0.00 \%$ & $100 \%$ & $0.00 \%$ & $100.00 \%$ & $0.00 \%$ & $76.92 \%$ \\
\hline Western Sahara & 8 & 1 & 10 & 1 & $10.00 \%$ & $80 \%$ & $11.11 \%$ & $88.89 \%$ & $0.00 \%$ & $80.00 \%$ \\
\hline MS Zaandam & & 2 & 9 & 7 & $22.22 \%$ & $0 \%$ & $100.00 \%$ & $0.00 \%$ & $0.00 \%$ & $0.00 \%$ \\
\hline Anguilla & 3 & & 3 & 0 & $0.00 \%$ & $100 \%$ & $0.00 \%$ & $100.00 \%$ & $0.00 \%$ & $100.00 \%$ \\
\hline Total & $20,811,464$ & $\mathbf{9 2 4 , 5 7 7}$ & $28,943,657$ & $7,207,616$ & $3.19 \%$ & $72 \%$ & $4.25 \%$ & $95.75 \%$ & $0.73 \%$ & $68.72 \%$ \\
\hline
\end{tabular}

This work is licensed under a Creative Commons Attribution 4.0 United States License.

This journal is published by the University Library System of the University of Pittsburgh as part of its D-Scribe Digital Publishing Program and is cosponsored by the University of Pittsburgh Press. 
Table S2. The estimated CFRs and CRRs for each included country ( $n=38$ ) against the county's population, GDP, number of hospital beds per 1,000 people, number of ICU beds per 100,000 people, and number of ventilators between the three different proposed models of estimation.

\begin{tabular}{|c|c|c|c|c|c|c|c|c|c|c|c|c|c|c|c|}
\hline \multirow{2}{*}{ Country } & \multirow{2}{*}{$\begin{array}{c}\text { Total } \\
\text { Recovered }\end{array}$} & \multirow{2}{*}{$\begin{array}{c}\text { Total } \\
\text { deaths }\end{array}$} & \multirow{2}{*}{$\begin{array}{l}\text { Total } \\
\text { cases }\end{array}$} & \multirow{2}{*}{$\begin{array}{c}\text { Active } \\
\text { cases }\end{array}$} & \multirow{2}{*}{$\begin{array}{c}\text { Population } \\
\text { (Million) }\end{array}$} & \multirow{2}{*}{$\begin{array}{c}\text { GDP } \\
\text { (Trillion) }\end{array}$} & \multirow{2}{*}{$\begin{array}{c}\text { Number of } \\
\text { hospital beds } \\
\text { per } 1,000 \\
\text { people } \\
\end{array}$} & \multirow{2}{*}{$\begin{array}{c}\text { Number of } \\
\text { ICU Beds } \\
\text { per } 100,000 \\
\text { people }\end{array}$} & \multirow{2}{*}{$\begin{array}{l}\text { Number of } \\
\text { Ventilators }\end{array}$} & \multicolumn{2}{|c|}{ Model 1} & \multicolumn{2}{|c|}{ Model 2} & \multicolumn{2}{|c|}{ Model 3} \\
\hline & & & & & & & & & & CFR1 & CRR1 & CFR2 & CRR2 & CFR3 & CRR3 \\
\hline USA & 36,948 & 23,644 & 587,155 & 526,563 & 327.2 & 19.39 & 2.77 & 34.7 & 177,000 & 4.03 & 6.29 & 39.02 & 60.98 & 6.96 & 12.18 \\
\hline Spain & 64,727 & 17,756 & 170,099 & 87,616 & 46.66 & 1.311 & 2.97 & 9.7 & NR & 10.44 & 38.05 & 21.53 & 78.47 & 12.37 & 44.83 \\
\hline Italy & 35,435 & 20,465 & 159,516 & 103,616 & 60.48 & 1.935 & 3.18 & 12.5 & 3,000 & 12.83 & 22.21 & 36.61 & 63.39 & 14.85 & 28.73 \\
\hline France & 27,718 & 14,967 & 136,779 & 94,094 & 66.99 & 2.583 & 5.98 & 11.6 & 30,000 & 10.94 & 20.26 & 35.06 & 64.94 & 14.57 & 27.14 \\
\hline Germany & 64,300 & 3,194 & 130,072 & 62,578 & 82.79 & 3.677 & 8.00 & 29.2 & 25,000 & 2.46 & 49.43 & 4.73 & 95.27 & 3.55 & 66.79 \\
\hline UK & 135 & 11,329 & 88,621 & 76,948 & 66.44 & 2.622 & 2.54 & 6.6 & 8,175 & 12.78 & 0.15 & 98.82 & 1.18 & 18.35 & ----- \\
\hline China & 77,738 & 3,341 & 82,249 & 1,170 & 1,386 & 12.24 & 4.34 & 3.6 & NR & 4.06 & 94.52 & 4.12 & 95.88 & 5.64 & 93.80 \\
\hline Iran & 45,983 & 4,585 & 73,303 & 22,735 & 81.16 & 0.4395 & 1.5 & 4.8 & NR & 6.25 & 62.73 & 9.07 & 90.93 & 2.64 & 14.58 \\
\hline Turkey & 3,957 & 1,296 & 61,049 & 55,796 & 80.81 & 0.8511 & 2.81 & 47.1 & 17,000 & 2.12 & 6.48 & 24.67 & 75.33 & 8.83 & 98.30 \\
\hline Belgium & 6,707 & 3,903 & 30,589 & 19,979 & 11.4 & 0.4927 & 5.76 & 15.9 & NR & 12.76 & 21.93 & 36.79 & 63.21 & 18.39 & 28.16 \\
\hline Netherlands & 250 & 2,823 & 26,551 & 23,478 & 17.18 & 0.8262 & 3.32 & 6.4 & NR & 10.63 & 0.94 & 91.86 & 8.14 & 9.27 & 54.82 \\
\hline Switzerland & 13,700 & 1,138 & 25,688 & 10,850 & 8.57 & 0.6789 & 4.53 & 11.0 & NR & 4.43 & 53.33 & 7.67 & 92.33 & 1.23 & 12.03 \\
\hline Canada & 7,756 & 780 & 25,680 & 17,144 & 37.59 & 1.653 & 2.52 & 13.5 & NR & 3.04 & 30.20 & 9.14 & 90.86 & 6.03 & 45.96 \\
\hline Brazil & 173 & 1,355 & 23,723 & 22,195 & 209.3 & 2.056 & 2.3 & NR & NR & 5.71 & 0.73 & 88.68 & 11.32 & 16.13 & 1.12 \\
\hline Russia & 1,470 & 148 & 18,328 & 16,710 & 144.5 & 1.578 & 8.05 & 8.3 & 40,000 & 0.81 & 8.02 & 9.15 & 90.85 & 8.25 & 103.11 \\
\hline Portugal & 277 & 535 & 16,934 & 16,122 & 10.29 & 0.2176 & 3.39 & 4.2 & 1,400 & 3.16 & 1.64 & 65.89 & 34.11 & 4.36 & 3.87 \\
\hline Austria & 7,343 & 368 & 14,041 & 6,330 & 24.6 & 1.323 & 3.84 & 9.1 & 1,314 & 2.62 & 52.30 & 4.77 & 95.23 & 3.74 & 17.66 \\
\hline Israel & 1,855 & 116 & 11,586 & 9,615 & 8.712 & 0.3509 & 3.02 & NR & NR & 1.00 & 16.01 & 5.89 & 94.11 & 5.12 & 0.69 \\
\hline Sweden & 381 & 919 & 10,948 & 9,648 & 10.12 & 0.538 & 2.22 & 5.8 & NR & 8.39 & 3.48 & 70.69 & 29.31 & 4.20 & 96.93 \\
\hline
\end{tabular}

This work is licensed under a Creative Commons Attribution 4.0 United States License.

This journal is published by the University Library System of the University of Pittsburgh as part of its D-Scribe Digital Publishing Program and is cosponsored by the University of Pittsburgh Press. 


\begin{tabular}{|c|c|c|c|c|c|c|c|c|c|c|c|c|c|c|c|}
\hline Ireland & 25 & 365 & 10,647 & 10,257 & 4.83 & 0.3337 & 2.96 & 6.5 & NR & 3.43 & 0.23 & 93.59 & 6.41 & 3.32 & 63.76 \\
\hline S. Korea & 7,534 & 222 & 10,564 & 2,808 & 51.4 & 1.531 & 12.27 & 10.6 & 9,795 & 2.10 & 71.32 & 2.86 & 97.14 & 15.65 & 5.70 \\
\hline India & 1,181 & 358 & 10,453 & 8,914 & 1,339 & 2.597 & 0.53 & 5.2 & 40,000 & 3.42 & 11.30 & 23.26 & 76.74 & 1.78 & 37.54 \\
\hline Peru & 2,642 & 216 & 9,784 & 6,926 & 32.17 & 0.2114 & 1.6 & NR & NR & 2.21 & 27.00 & 7.56 & 92.44 & 3.11 & 96.101 \\
\hline Japan & 799 & 143 & 7,645 & 6,703 & 126.8 & 4.872 & 13.05 & 7.3 & 32,586 & 1.87 & 10.45 & 15.18 & 84.82 & 2.97 & 14.32 \\
\hline Ecuador & 597 & 355 & 7,529 & 6,577 & 16.62 & 0.1031 & 1.50 & NR & NR & 4.72 & 7.93 & 37.29 & 62.71 & 1.71 & 54.75 \\
\hline Chile & 2,367 & 82 & 7,525 & 5,076 & 18.05 & 0.2771 & 2.2 & 2.11 & NR & 1.09 & 31.46 & 3.35 & 96.65 & 6.32 & 13.97 \\
\hline Poland & 487 & 245 & 6,934 & 6,202 & 37.98 & 0.5245 & 6.62 & 6.9 & 10,100 & 3.53 & 7.02 & 33.47 & 66.53 & 5.20 & 14.70 \\
\hline Romania & 914 & 331 & 6,633 & 5,388 & 19.53 & 0.2118 & 6.3 & 21.4 & NR & 4.99 & 13.78 & 26.59 & 73.41 & 6.45 & 26.51 \\
\hline Norway & 32 & 134 & 6,605 & 6,439 & 5.368 & 0.3988 & 3.6 & 8 & 800 & 2.03 & 0.48 & 80.72 & 19.28 & 1.46 & 21.02 \\
\hline Australia & 3,494 & 61 & 6,394 & 2,839 & 24.6 & 1.323 & 3.84 & 9.1 & 1,314 & 0.95 & 54.64 & 1.72 & 98.28 & 2.27 & 29.08 \\
\hline Denmark & 2,235 & 285 & 6,318 & 3,798 & 5.603 & 0.3249 & 2.61 & 6.7 & NR & 4.51 & 35.38 & 11.31 & 88.69 & 10.53 & 42.55 \\
\hline Czech Republic & 519 & 143 & 6,059 & 5,397 & 10.65 & 0.2157 & 6.63 & 11.6 & 3,529 & 2.36 & 8.57 & 21.60 & 78.40 & 5.78 & 64.21 \\
\hline Pakistan & 1,097 & 96 & 5,707 & 4,514 & 197 & 0.305 & 0.6 & NR & 34,000 & 1.68 & 19.22 & 8.05 & 91.95 & 3.14 & 0.61 \\
\hline Mexico & 1,964 & 332 & 5,014 & 2,718 & 129.2 & 1.15 & 1.38 & 1.2 & 2,050 & 6.62 & 39.17 & 14.46 & 85.54 & 3.87 & 26.20 \\
\hline Saudi Arabia & 805 & 65 & 4,934 & 4,064 & 32.94 & 0.6838 & 2.7 & NR & NR & 1.32 & 16.32 & 7.47 & 92.53 & 1.50 & 89.40 \\
\hline Philippines & 242 & 315 & 4,932 & 4,375 & 104.9 & 0.3136 & 1.0 & NR & NR & 6.39 & 4.91 & 56.55 & 43.45 & 0.80 & 25.56 \\
\hline Malaysia & 2,276 & 77 & 4,817 & 2,464 & 31.62 & 0.3145 & 1.9 & NR & NR & 1.60 & 47.25 & 3.27 & 96.73 & 11.99 & 14.14 \\
\hline Indonesia & 380 & 399 & 4,557 & 3,778 & 264 & 1.016 & 1.2 & $\mathrm{NR}$ & NR & 8.76 & 8.34 & 51.22 & 48.78 & 9.36 & 12.17 \\
\hline World & 445,023 & 119,699 & $1,925,179$ & $\mathbf{1 , 3 6 0 , 4 5 7}$ & ---- & ---- & ---- & ---- & ---- & 6.22 & 23.12 & 21.20 & 78.80 & 8.67 & 32.23 \\
\hline
\end{tabular}

This work is licensed under a Creative Commons Attribution 4.0 United States License.

This journal is published by the University Library System of the University of Pittsburgh as part of its D-Scribe Digital Publishing Program and is cosponsored by the University of Pittsburgh Press. 